\title{
Sistem Administrasi Permintaan dan Pengiriman Alat Kesehatan pada PT. Samudra Farma Bengkulu
}

\author{
Asnawati ${ }^{1}$, Venny Novita Sari ${ }^{2}$ \\ 1,2 Program Studi Sistem Informasi, Universitas Dehasen Bengkulu \\ Email : asnawati_asna@yahoo.com
}

\begin{abstract}
This research aims to make the system making demand administration and shipping of medical equipment to the PT. Samudra Farma Bengkulu. With this program are expected to help in providing the data update demands and shipping medical equipment. The method used in this research is the System Development Life Cycle (SDLC). SDLC it serves to illustrate the main stages and steps of each stage are broadly divided into three (3) activities of the analysis, design and implementation, while the proposed methods of data collection are observation, interviews, and literature. The results of this research is a medical equipment data reports, the data demands, acceptance and shipping medical equipment report. The program was created by using Microsoft Access and Microsoft Visual Basic Programming Language 6.0.
\end{abstract}

Keyword : administration, Demand and shipping, Visual Basic 6.0

Intisari-Penelitian bertujuan ini membuat pembuatan sistem administrasi permintaan dan pengiriman alat kesehatan pada PT. Samudra Farma Bengkulu. Dengan program ini diharapkan dapat membantu dalam memberikan informasi data permintaan dan pengiriman alat kesehatan. Metode yang digunakan dalam penelitian ini adalah System Development Life Cycle (SDLC). SDLC ini berfungsi untuk menggambarkan tahapan-tahapan utama dan langkah-langkah dari setiap tahapan yang secara garis besar terbagi dalam 3 (tiga) kegiatan yaitu analisis, desain dan implementasi sedangkan metode pengumpulan data yang diajukan adalah observasi, wawancara dan studi pustaka. Hasil dari penelitian ini berupa laporan data alat kesehatan, data permintaan, penerimaan dan laporan pengiriman alat kesehatan. Program ini dibuat dengan menggunakan Microsoft Acces dan Bahasa Pemrograman Microsoft Visual Basic 6.0.

Kata kunci : Administrasi, Permintaan dan Pengiriman, Visual Basic 6.0

\section{PENDAHULUAN}

Perkembangan teknologi khususnya komputer pada saat sekarang ini mempunyai peranan yang sangat penting dalam kehidupan di masyarakat. Teknologi yang berkembang sesuai tuntutan zaman menjadi sarana yang sangat mendukung untuk menangani berbagai permasalahan yang timbul dalam mengelola dan menyelesaikan permasalahan yang ada diperusahaan, instansi-instansi maupun organisasi-organisasi lain.

Pekerjaan yang membutuhkan sistem komputerisasi ini sudah tentu membutuhkan sumber daya manusia atau (SDM) yang berkompetensi. Untuk itu tidak dapat dipungkiri lagi bahwa teknologi komputer yang spektakuler ini harus sejalan dengan kemampuan sumber daya manusia dalam menggunakan teknologi tersebut sebagai alat bantu serta menambah wawasan dalam dunia kerja.

PT. Samudra Farma adalah salah satu distibutor alat kesehatan yang ada di kota Bengkulu, dimana transaksi permintaan dan pengiriman barang yang terjadi pada toko PT. Samudra Farma ini sangat tinggi, namun sangat disayangkan semua proses transaksi tersebut masih dilakukan secara manual dengan kata lain semua transaksi dilakukan dengan pencatatan dibuku. Hal tersebut sangat rentan sekali dengan kesalahan-kesalahan yang terjadi seperti salah catat atau buku hilang atau yang paling fatal terjadi jika ada satu lembar atau satu halaman rusak sehingga akan membuat kesulitan untuk melakukan pengecekan dan perhitungan transaksi yang terjadi pada saat- 
saat tertentu.

Berdasarkan latar belakang diatas maka penulis tertarik untuk melakukan penelitian dengan judul Sistem Administrasi Permintaan dan Pengiriman Alat Kesehatan Pada PT. Samudra Farma Bengkulu.

\section{TINJAUAN PUSTAKA}

\section{A. Sistem}

Sistem adalah suatu jaringan kerja prosedurprosedur yang saling berhubungan, terkumpul bersama-sama untuk melakukan kegiatan atau untuk tujuan tertentu (Yakub, $2012: 29$ ).

Menurut Fathansyah (2012 : 47) sistem adalah sebuah tatanan (keterpaduan) yang terdiri atas sejumlah komponen fungsional (dengan satuan fungsi dan tugas khusus) yang saling berhubungan dan secara bersama-sama bertujuan untuk memenuhi suatu proses tertentu.

\section{B. Administrasi}

Administrasi dalam arti sempit adalah kegiatan yang meliputi: catat-mencatat, surat-menyurat, pembukuan ringan, ketik-mengetik, agenda, dan sebagainya yang bersifat teknis ketatausahaan. Sedangkan administrasi dalam arti luas adalah seluruh proses kerja sama antara dua orang atau lebih dalam mencapai tujuan dengan memanfaatkan sarana prasarana tertentu secara berdaya guna dan berhasil guna.

Menurut Mufiz (2004 : 14) administrasi adalah suatu rangkaian kegiatan yang dilakukan oleh sekelompok orang dalam bentuk kerjasama untuk mencapai tujuan tertentu.

Dari beberapa pengertian diatas dapat disimpulkan bahwa administrasi adalah suatu jaringan kerja yang terdiri atas sejumlah komponen fungsional yang saling berhubungan untuk melakukan kegiatan mencatat, pembukuan dengan memanfaatkan sarana dan sarana tertentu secara berdaya guna dan berhasil guna untuk memenuhi suatu proses atau tujuan tertentu.

\section{Permintaan dan Pengiriman}

Permintaan adalah jumlah barang yang diminta oleh konsumen pada suatu pasar (Fachreza, dkk, 2012 : 1). Sedangkan menurut Sholeh (2008 : 2) permintaan dalam konteks ekonomi didefinisihkan sebagai jumlah maksimum suatu barang atau jasa yang dikehendaki seorang pembeli untuk dibelinya pada setiap kemungkinan harga dalam jangka waktu tertentu.

Dari beberapa pengertia diatas dapat disimpulkan bahwa permintaan adalah jumlah barang atau jasa yang diminta oleh konsumen pada setiap kemungkinan harga tertentu dalam suatu pasar.

Pengiriman barang adalah segala upaya yang diselenggarakan secara sendiri atau bersamasama dalam satu organisasi untuk memberikan pelayanan jasa berupa pengiriman barang antar kota (Rowianto,dkk, 2008 : 4).

\section{Visual Basic 6.0}

Menurut Yuswanto (2008: 3), Visual Basic adalah salah satu development tools untuk membangun aplikasi dalam lingkungan windows. Dalam perkembangan aplikasi, Visual Basic menggunakan pendekatan visual untuk merancang user interface dalam bentuk form, sedangkan untuk kodingnya menggunakan dialok bahasa basic. Visual Basic telah menjadi tools yang terkenal bagi para pemula maupun para developer.

\section{E. Konsep dan Perancangan Database}

Menurt Fathansyah (2012: 2) basis data adalah himpunan kelompok data (arsip) yang saling berhubungan yang diorganisasi sedemikian rupa agar kelak dapat dimanfaatkan kembali dengan cara yang cepat dan mudah. Adapun istilah-istilah yang terdapat dalam database, diantaranya adalah:

1. Entity adalah orang, tempat, kejadian atau konsep yang informasinya direkam.

2. Atribut merupakan setiap entity mempunyai atribut atau sebutan untuk mewakili entity.

3. Field (column) yaitu tempat menampung 
atau menyimpan atribut atau ciri - ciri suatu objek.

4. Record (row) yaitu tempat menyimpan satu entitas data.

5. File kumpulan record -record sejenis yang mempunyai panjang elemen yang sama, atribut yang sama namun berbeda - beda fieldnya.

6. Relasi merupakan suatu hubungan antar satu tabel denga tabel yang lain. Hubungan ini dapat berbentuk one to one, one to many, many to one dan many to many.

7. Database merupakan sekumpulan file file yang mempunyai kaitan satu file dengan file yang lain sehingga membentuk satu bangunan data untuk menginformasikan satu organisasi dalam batasan tertentu.

8. Screen merupakan tampilan layar untuk menampilkan data. Tampilan layar ini sebernarnya sama dengan sebuah formulir tercetak.

9. Report atau laporan yaitu media untuk menampilkan hasil pengelohan. Laporan dapat berbentuk hardcopy (tercetak) ataupun softcopy (tidak tercetak).

\section{METODOLOGI PENELITIAN}

\section{A. Metode Perancangan Sistem}

\section{1) Analisa Sistem Aktual}

Proses permintaan dan pengiriman alat kesehatan pada PT. Samudra Farma pada saat ini masih menggunakan pencatatan dibuku dan pengumpulan bukti permintaan dan pengiriman alat kesehatan tersebut, hal ini terkadang tidak tersimpan dengan baik, maka administrasi perusahaan sering mengalami banyak kesalahan dan kendala karena data tidak lengkap.

\section{2) Analisa Sistem Baru}

Analisa Sistem Baru merupakan analisa kebutuhan dalam membuat perancangan aplikasi permintaan dan pengiriman alat kesehatan pada PT.
Samudra Farma Bengkulu. Untuk mengetahui hal-hal yang dibutuhkan oleh aplikasi, maka dibutuhkan suatu rancangan sistem baru. Rancangan tersebut meliputi tata cara pembuatan laporan, pembuatan Diagram Konteks, pembuatan Data Flow Diagram (DFD), Entity Relationship Diagram (ERD), Rancangan File, Rancangan Tampilan dan Rancangan Laporan.

\section{a) Diagram Konteks}

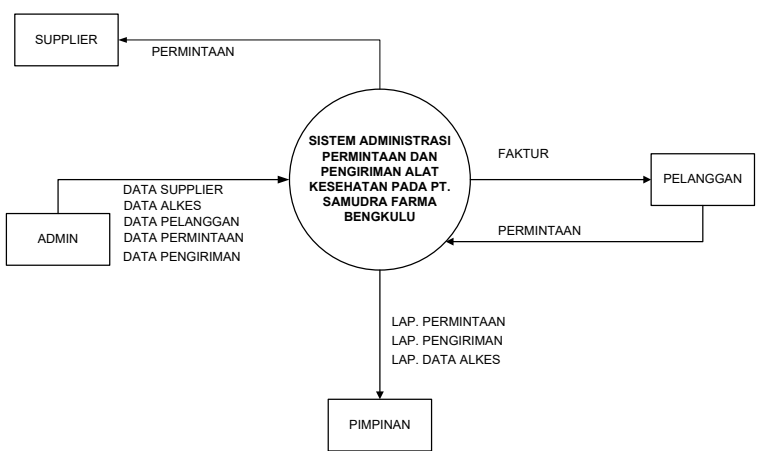

Gambar 1. Diagram Konteks

\section{b) Diagram Level 0}

Diagram level 0 menggambarkan seluruh kegiatan yang terdapat pada sistem secara jelas. Diagram level 0 terdiri dari 3 proses utama yaitu mengolah data master, data transaksi dan data laporan, seperti gambar berikut ini.

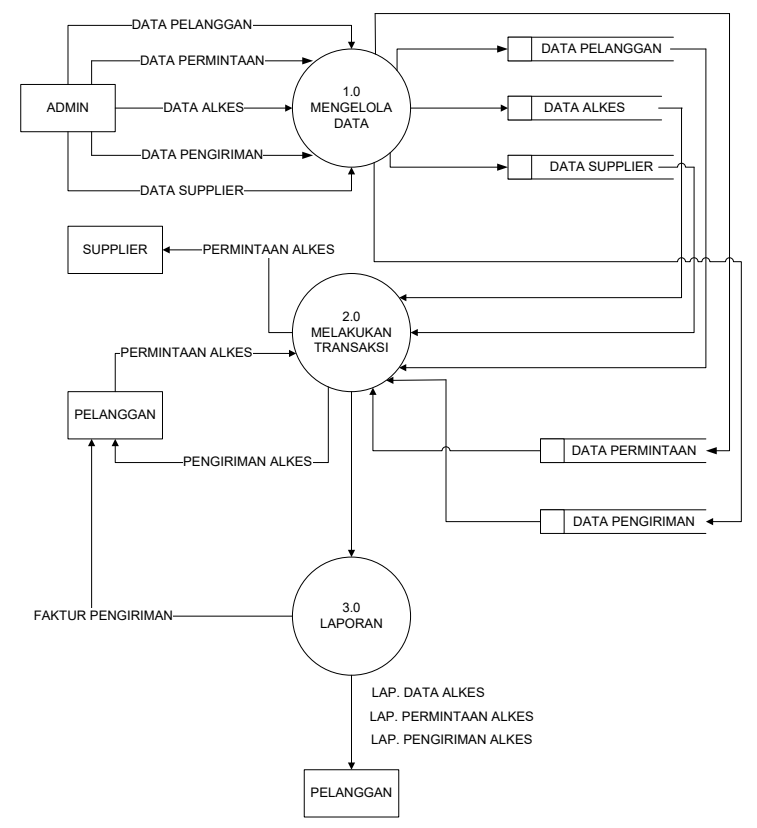

Gambar 2. DFD Level 0 


\section{c) Hierarchy Input Proses And Output (HIPO)}

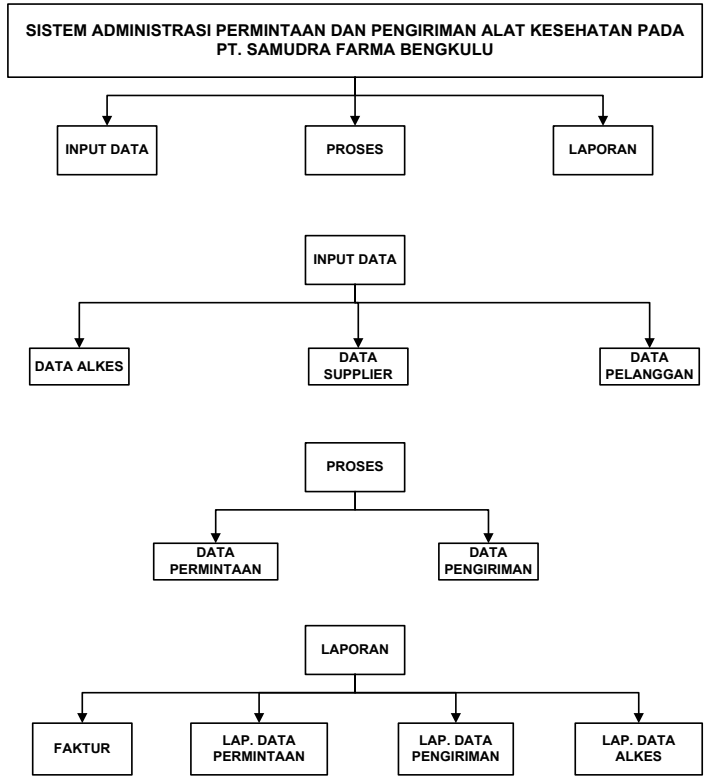

Gambar 3. HIPO

\section{d) Entity Relationship Diagram (ER-D)}

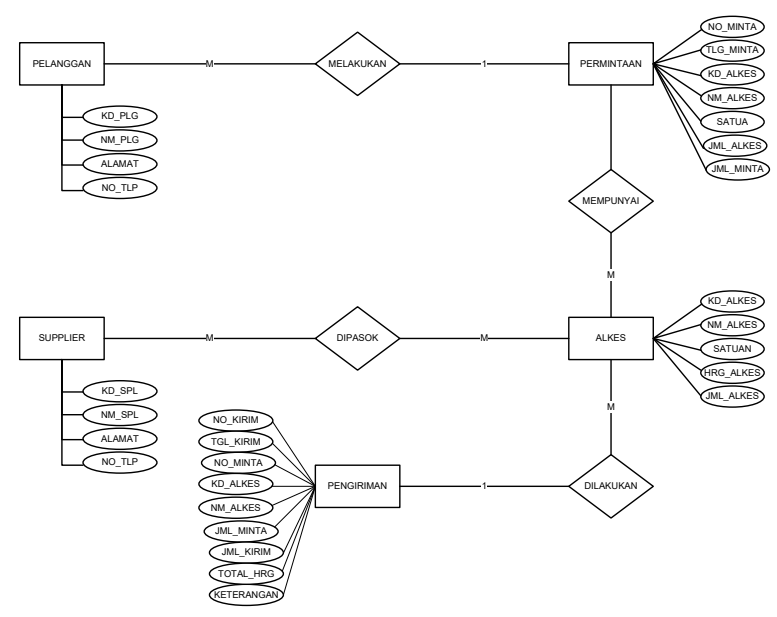

Gambar 4. ERD

\section{e) Struktur Menu}

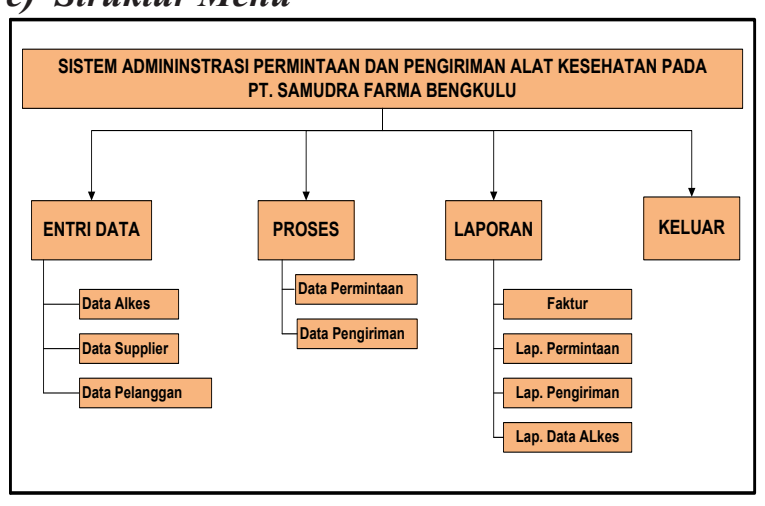

Gambar 5. Struktur Menu

\section{f) Rancangan Tabel}

\section{Table Admin}

Primary Key

Secondary Key

Tabel 1. Rancangan Tabel Admin

\begin{tabular}{|l|l|l|l|l|}
\hline No & Name Field & Type Data & Width & Description \\
\hline 1 & Username & Text & 15 & Nama user \\
\hline 2 & Password & Text & 15 & Password user \\
\hline
\end{tabular}

\section{Tabel Supplier}

$\begin{array}{ll}\text { Primary Key } & \text { : Kd_Spl } \\ \text { Secondary Key } & :-\end{array}$

Tabel 2. Rancangan Tabel Supplier

\begin{tabular}{|l|l|l|l|l|}
\hline No & Name Field & Type Data & Width & Description \\
\hline 1 & Kd_spl & Number & 5 & Kode Supplier \\
\hline 2 & Nm_spl & Text & 35 & Nama Suplier \\
\hline 3 & Alamat & Text & 50 & Alamat Suplier \\
\hline 4 & No.Telp & Number & 15 & No.Telp Suplier \\
\hline
\end{tabular}

\section{Tabel Alkes}

Primary Key : : kd_alkes

Secondary Key $\quad$ : kd_spl

Tabel 3. Rancangan Tabel Alkes

\begin{tabular}{|l|l|l|l|l|}
\hline No & Name Field & Type Data & Width & Description \\
\hline 1 & Kd alkes & Number & 5 & Kode Alkes \\
\hline 2 & Nm alkes & Text & 35 & Nama Alkes \\
\hline 3 & Kd Spl & Number & 5 & Kode Suplier \\
\hline 4 & Satuan & Text & 10 & Satuan Alkes \\
\hline 5 & Hrg Alkes & Number & 6 & Harga Alkes \\
\hline 6 & Jml Alkes & Number & 4 & Jumlah Akes \\
\hline 7 & Total & Number & 9 & Total Harga Alkes \\
\hline
\end{tabular}

\section{Tabel Pelanggan}

Primary Key : Kd_Plg

Secondary Key : : -

Tabel 4. Rancangan Tabel Pelanggan

\begin{tabular}{|l|l|l|l|l|}
\hline No & Name Field & Type Data & Width & Description \\
\hline 1 & Kd plg & Text & Number & Kode Pelanggan \\
\hline 2 & Nm plg & Text & 35 & Nama Pelanggan \\
\hline 3 & Alamat & Text & 50 & Alamat Pelanggan \\
\hline 4 & No.Telp & Text & Number & No. Telp Pelanggan \\
\hline
\end{tabular}

\section{Tabel Permintaan}

Primary Key : No_Permintaan

Secondary Key : Kd_Alkes,Kd_plg

Tabel 5. Rancangan Tabel Permintaan

\begin{tabular}{|l|l|l|l|l|}
\hline No & Name Field & Type Data & Width & Description \\
\hline 1 & No minta & Number & 5 & Nomor Permintaan \\
\hline 2 & Tgl minta & Date/Time & 8 & Tanggal Permintaan \\
\hline 3 & Kd plg & Number & 5 & Kode Pelanggan \\
\hline 4 & Nm plg & Text & 35 & Nama Pelanggan \\
\hline 5 & Kd Alkes & Number & 5 & Kode Alkes \\
\hline 6 & Nm Alkes & Text & 35 & Nama Alkes \\
\hline 7 & Satuan & Text & 10 & Satuan Barang \\
\hline 8 & Jml Alkes & Integer & 4 & Jumlah Alkes \\
\hline 9 & Jml minta & Integer & 4 & Jumlah Permintaan \\
\hline 10 & Keterangan & Text & 50 & Keterangan \\
\hline
\end{tabular}




\section{Tabel Pengiriman}

Primary Key

: No_Kirim

Secondary Key

: No_minta

Tabel 6. Rancangan Tabel Pengiriman

\begin{tabular}{|l|l|l|l|l|}
\hline No & Name Field & Type Data & Width & Description \\
\hline 1 & No Kirim & Text & 5 & Nomor Pengiriman \\
\hline 2 & Tgl Kirim & Date/Time & 8 & Tanggal Pengiriamn \\
\hline 3 & No minta & Number & 5 & Nomor Permintaan \\
\hline 4 & Tgl minta & Date/Time & 8 & Tanggal Permintaan \\
\hline 5 & Kd plg & Number & 5 & Kode Pelanggan \\
\hline 6 & Nm plg & Text & 35 & Nama Pelanggan \\
\hline 7 & Kd Alkes & Number & 5 & Kode Alkes \\
\hline 8 & Nm Alkes & Text & 35 & Nama Alkes \\
\hline 9 & Satuan & Text & 10 & Satuan \\
\hline 10 & Total Hrg & Number & 8 & Total harga \\
\hline 11 & Jml kirim & Number & 4 & Jumlah Dikirim \\
\hline 12 & Keterangan & Text & 50 & Keterangan \\
\hline
\end{tabular}

\section{g) Rancangan Input}

\section{Menu Utama}

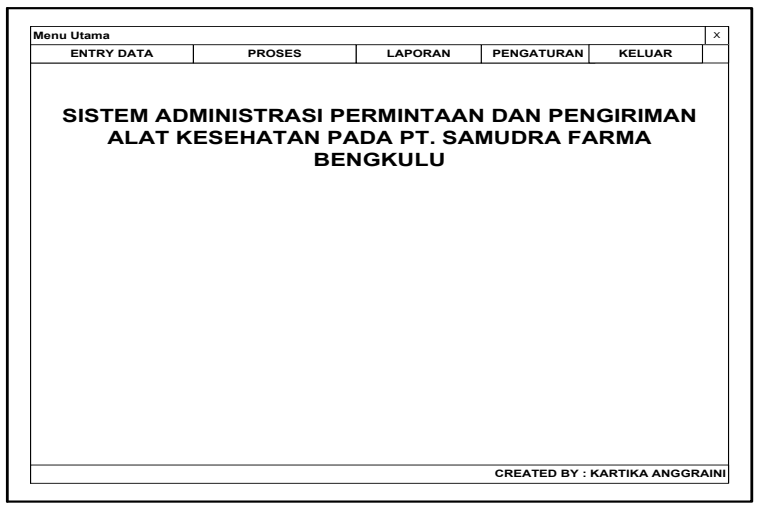

Gambar 6. Rancangan Menu Utama

\section{Rancangan Input Data Alkes}

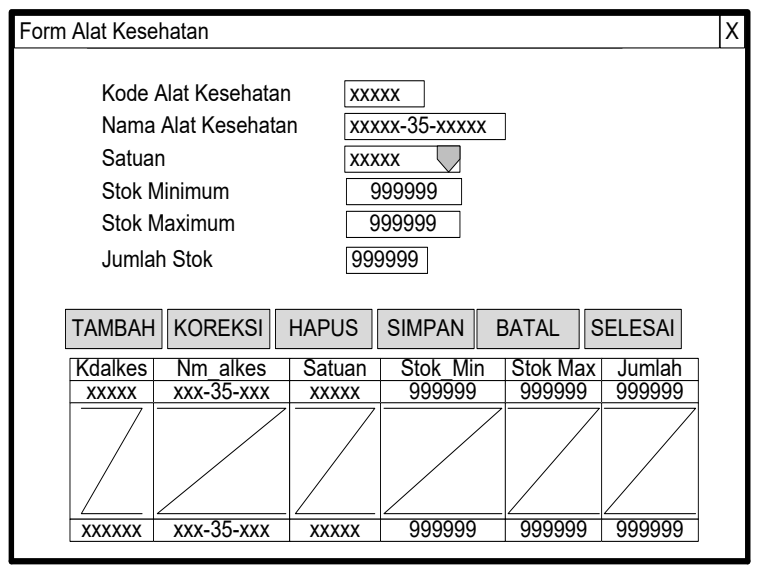

Gambar 7. Rancangan Input Data Alat Kesehatan

\section{Rancangan Input Data Suplier}

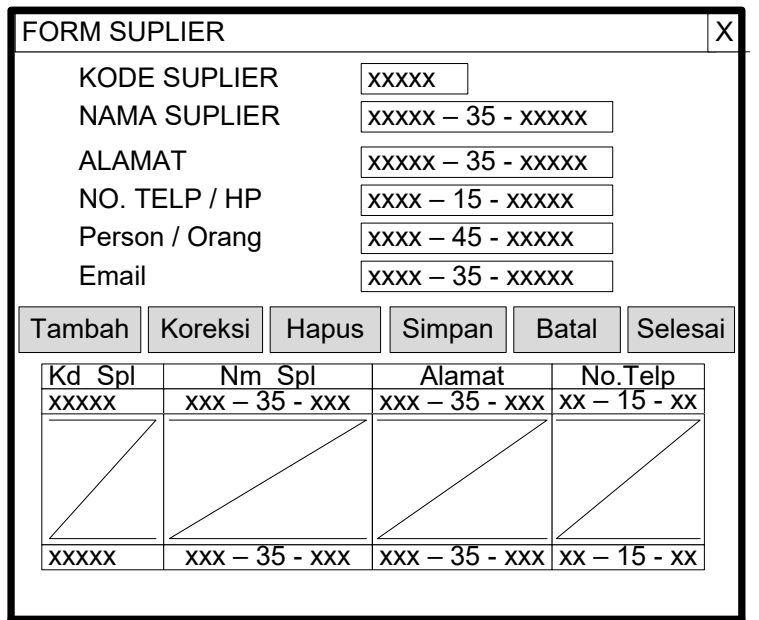

Gambar 8. Rancangan Input Data Suplier

\section{Rancangan Input Data Pelanggan}

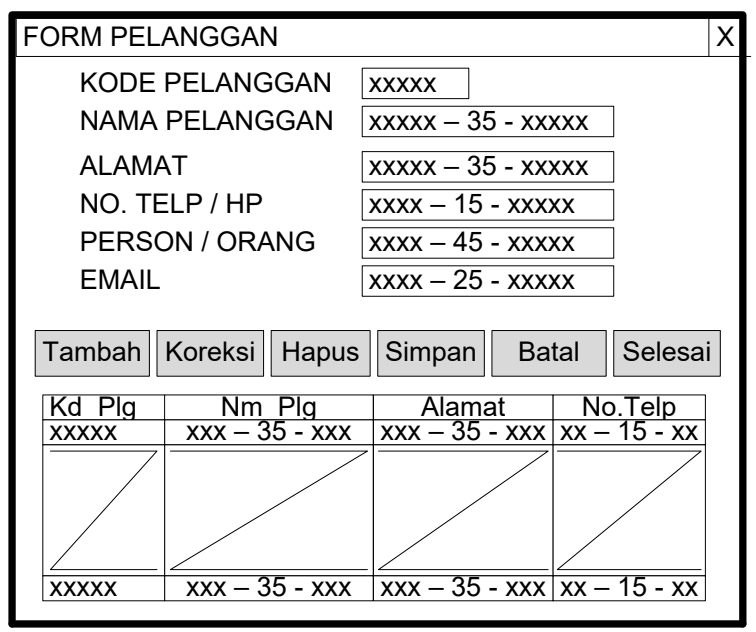

Gambar 9. Rancangan Input Data Pelanggan

\section{Rancangan Input Data Permintaan}

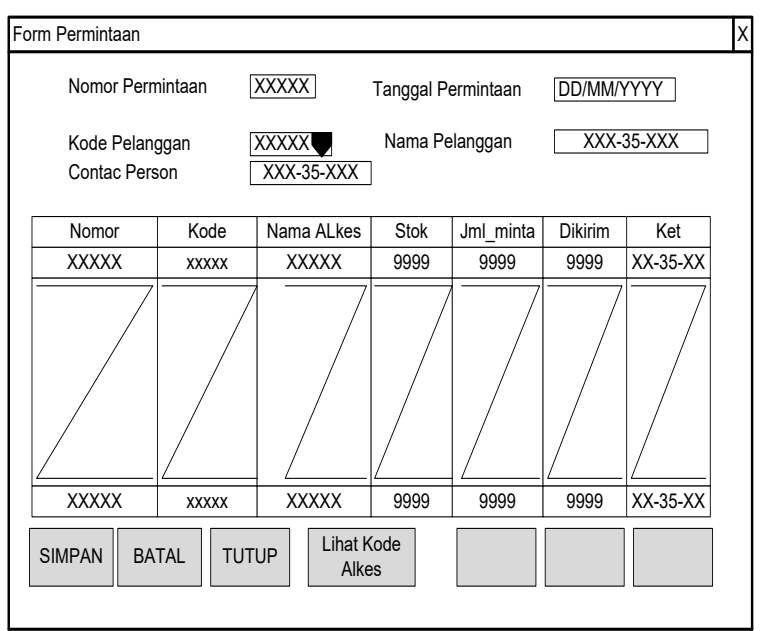

Gambar 10. Rancangan Input Data Permintaan 


\section{Rancangan Input Data Pengiriman}

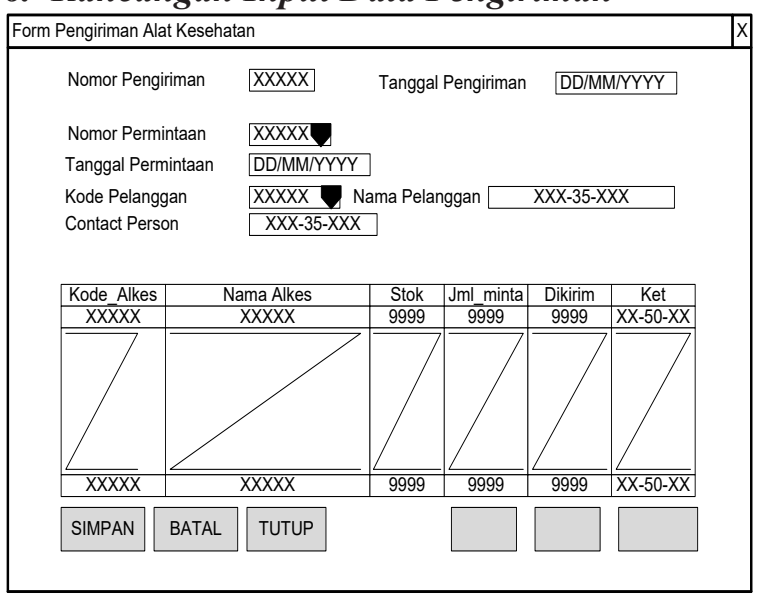

Gambar 11. Rancangan Input Data Pengiriman

\section{Rancangan Input Data Penerimaan Dari} Supplier

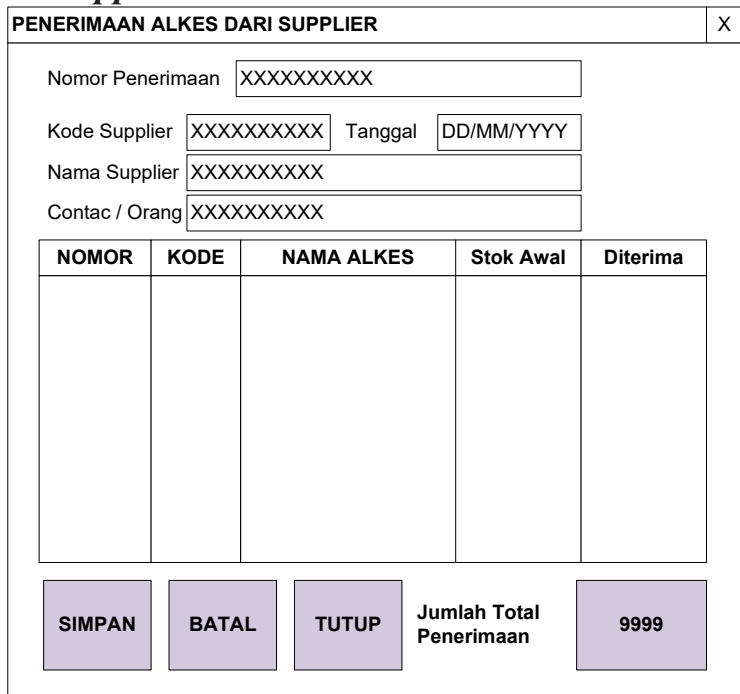

Gambar 12. Rancangan Penerimaan Dari Supplier

\section{Rancangan Cek Stok Alkes}

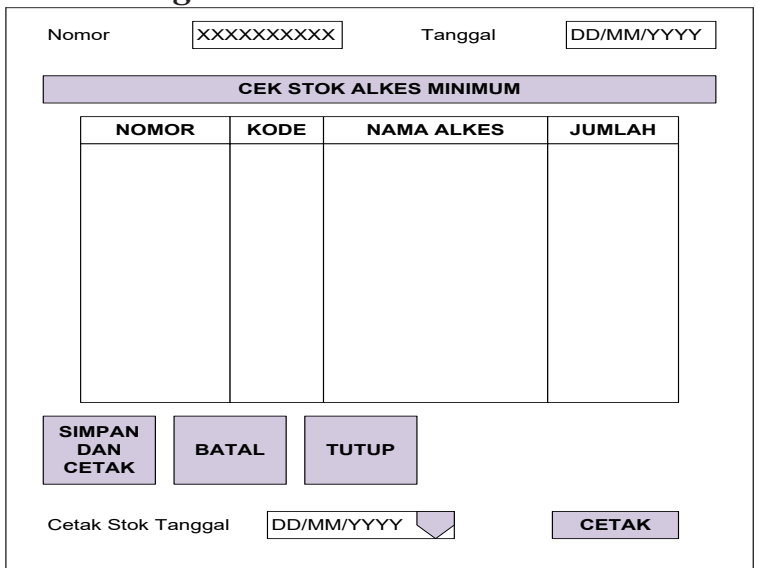

\section{h) Rancangan Output}

1. Output Master Alkes

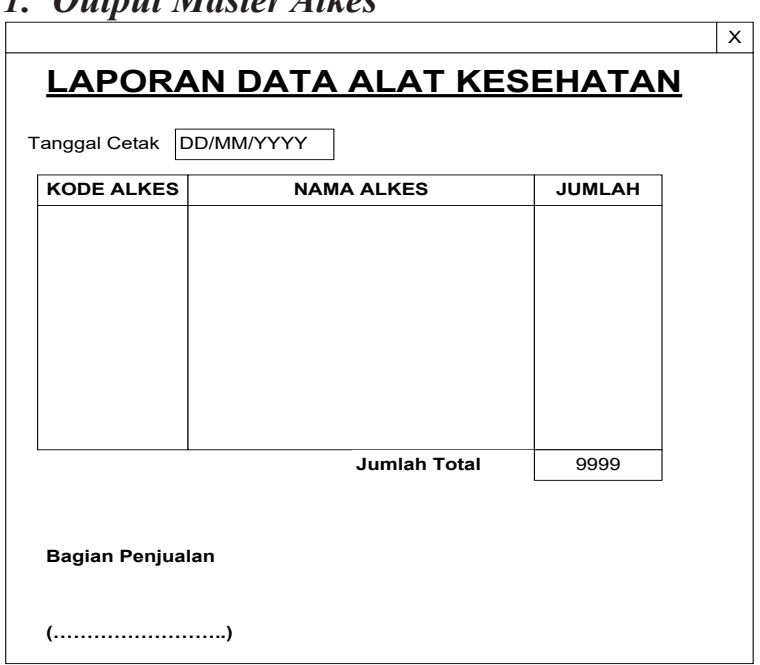

Gambar 14. Rancangan Output Master Data Alkes

\section{Laporan Master Data Supplier}

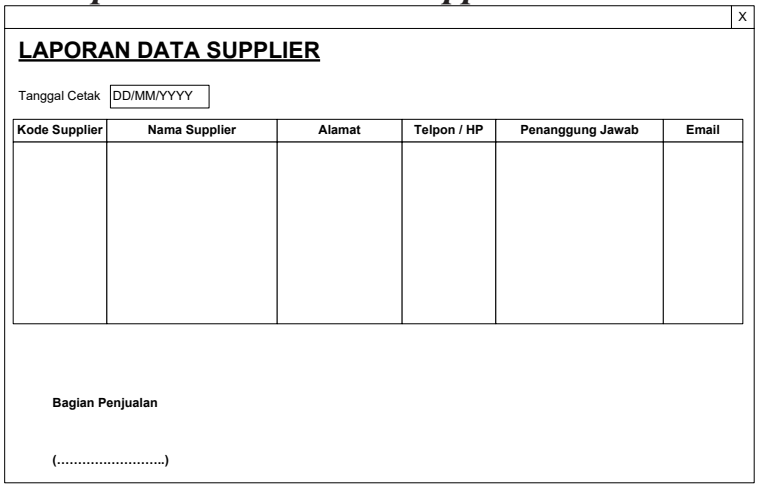

Gambar 15. Rancangan Output Master Data Supplier

\section{Laporan Master Data Pelanggan}

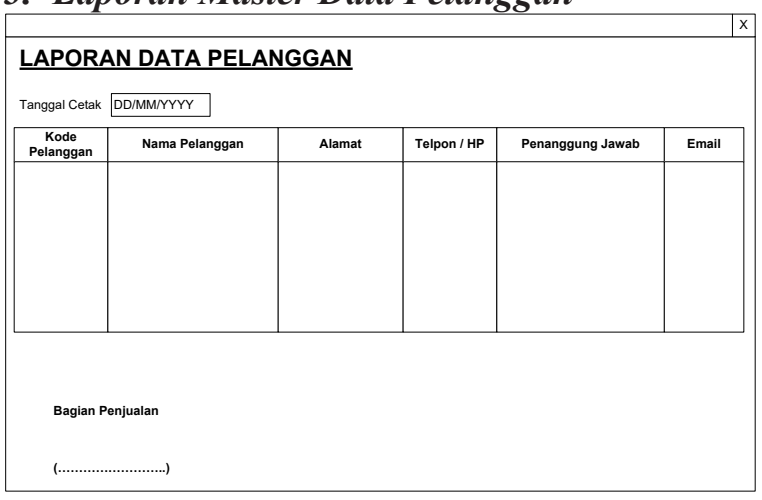

Gambar 16. Rancangan Output Master Data Pelanggan

Gambar 13. Rancangan Cek Stok Alkes 


\section{Laporan Transaksi}

Laporan transaksi merupakan laporan yang berisi seluruh laporan mulai dari laporan permintaan, penerimaan dan pengiriman seperti pada gambar berikut ini :

\begin{tabular}{|c|c|c|c|}
\hline LAPORAN TRAI & ISAKSI & & $x$ \\
\hline Perminta & Penerimaan & Pengiriman & \\
\hline Laporan $\mathrm{H}$ & arian & & \\
\hline Tanggal & DD/MM/YYYY & & \\
\hline Laporan Bu & Ianan & & \\
\hline Bulan & $X X X X X X X X X$ & & \\
\hline Tahun & $9999 \square$ & & \\
\hline & BANTUAN & TUTUP & \\
\hline
\end{tabular}

Gambar 17. Rancangan Menu Cetak Laporan

\section{Transaksi}

Dari gambar diatas, apabila ingin menampilkan laporan permintaan per hari maka, sistem akan meminta user untuk memilih combo tanggal saja, sedangkan untuk menampil laporan permintaan bulanan user diminta untuk memilih bulan dan tahun maka rancangan laporan harian dan bulan yang akan muncul akan tampak seperti gambar dibawah ini.

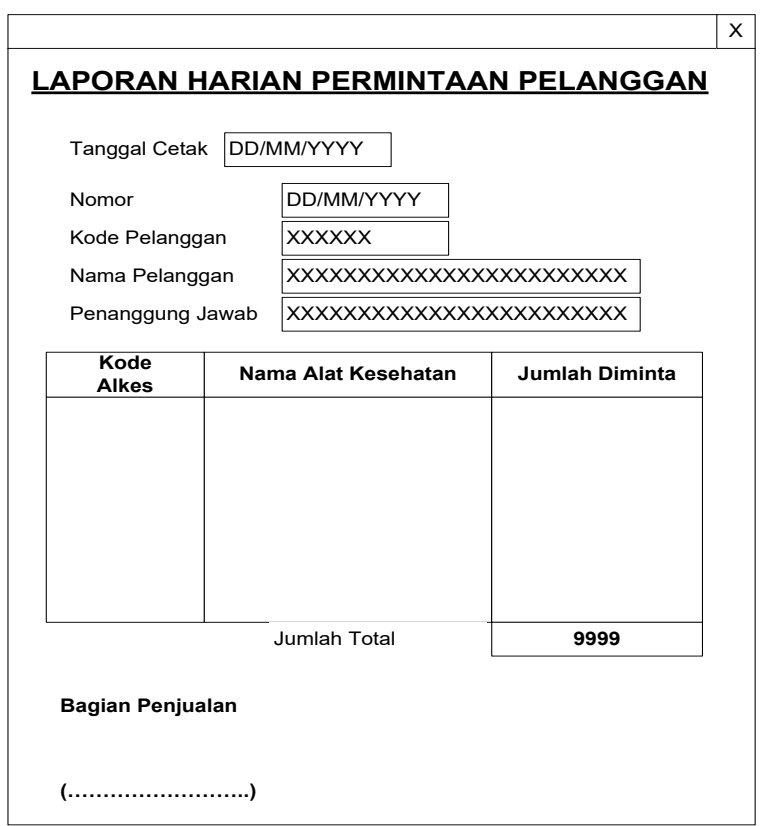

Gambar 18. Laporan Permintaan Harian

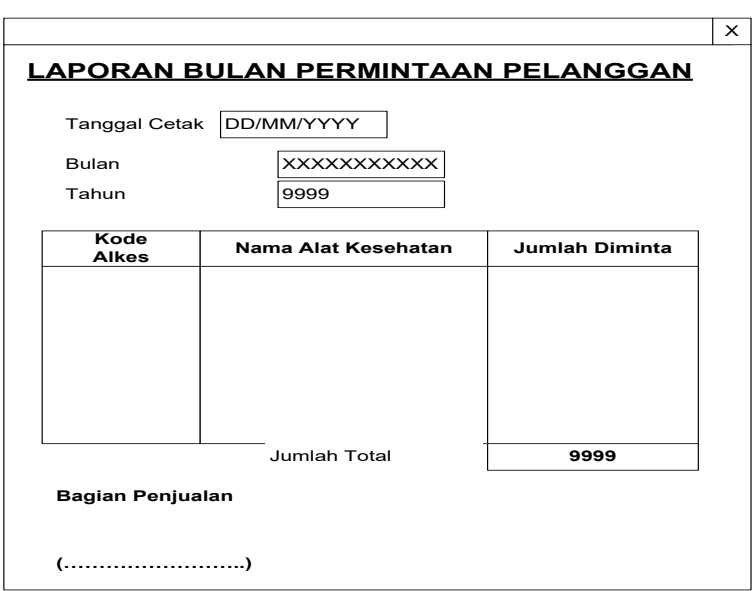

Gambar 19. Laporan Bulanan Permintaan Pelanggan

\section{Laporan Penerimaan Alat Kesehatan}

Laporan transaksi penerimaan merupakan laporan yang berisi seluruh laporan penerimaan dari supplier secara harian dan bulanan seperti pada gambar berikut ini :

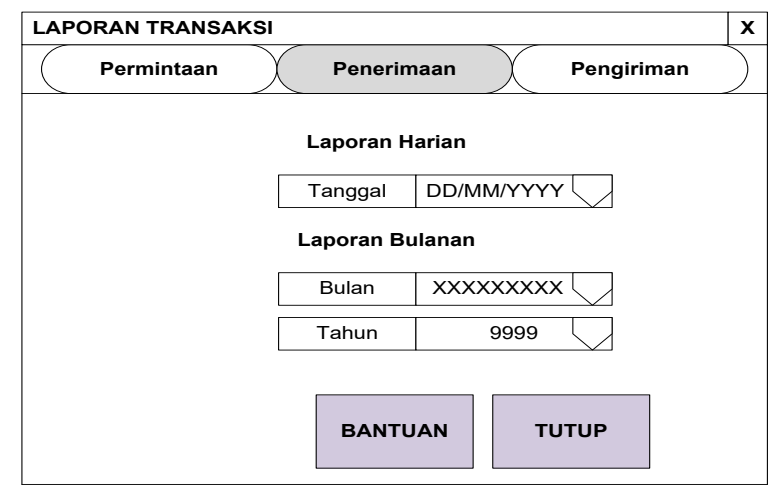

Gambar 20. Rancangan Cetak Laporan

Penerimaan

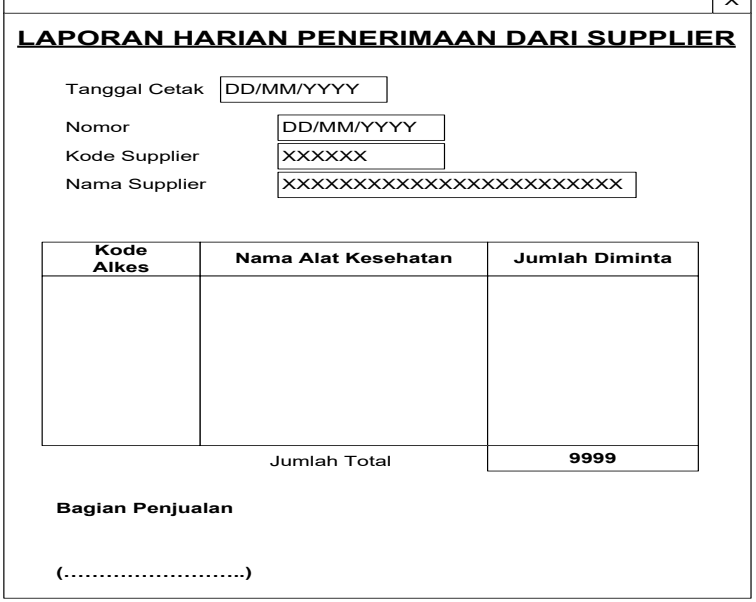

Gambar 21. Laporan Penerimaan Harian Dari Supplier 


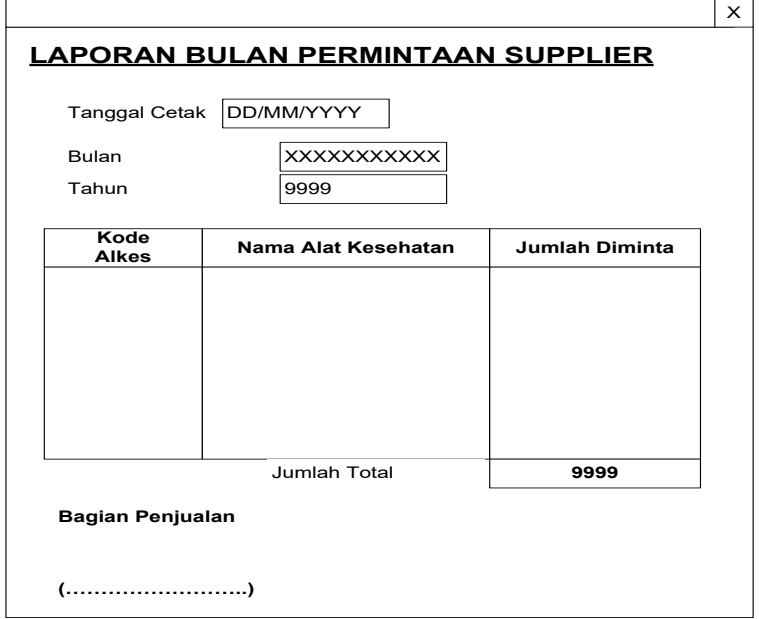

Gambar 22. Laporan Permintaan Dari Supplier

\section{Laporan Pengiriman Alat Kesehatan}

Laporan pengiriman alat kesehatan merupakan laporan yang berisi seluruh data pangiriman alat kesehatan secara harian dan bulanan seperti pada gambar berikut ini :

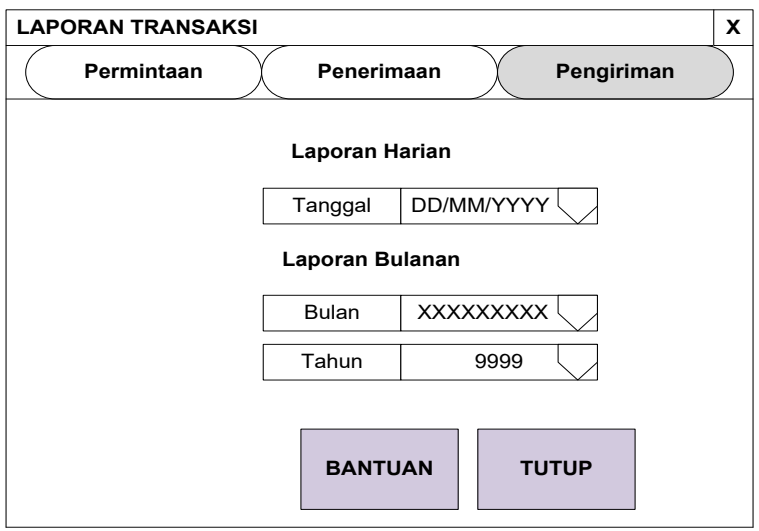

Gambar 23. Rancangan Cetak Pengiriman Alat Kesehatan

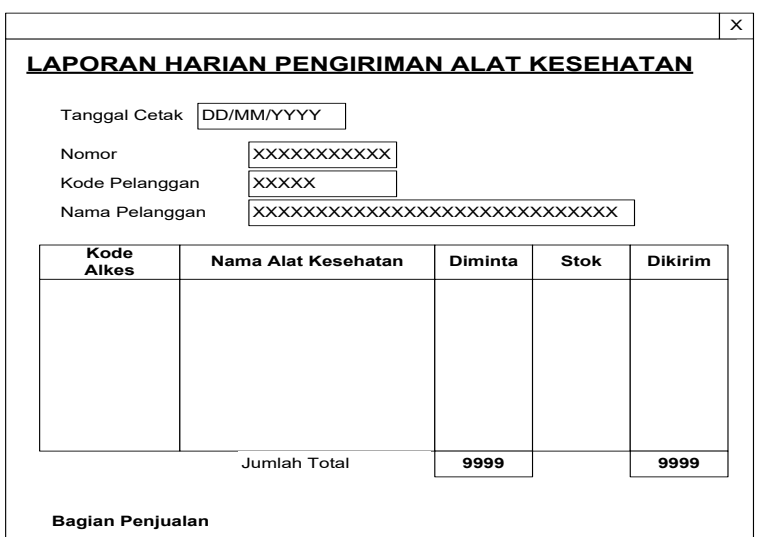

Gambar 24. Laporan Harian Pengiriman Alat Kesehatan

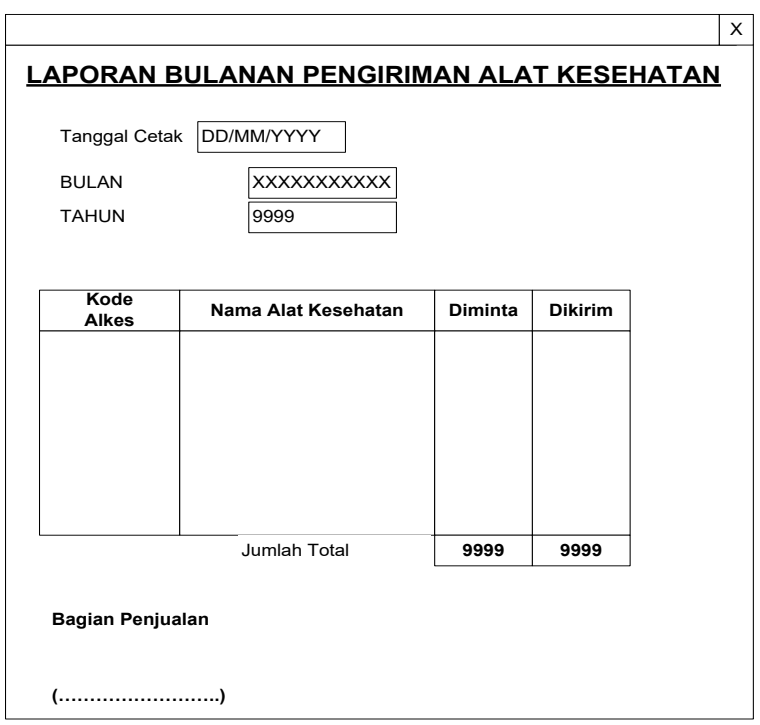

Gambar 25. Laporan Bulanan Pengiriman Alat Kesehatan

\section{Laporan Stok Alat Kesehatan Per Tanggal}

Laporan stok alat kesehatan merupakan laporan yang berfungsi untuk melakukan cros-cek alat kesehatan yang diterima dan keluar dari PT. Samudra Farma, seperti pada gambar berikut ini :

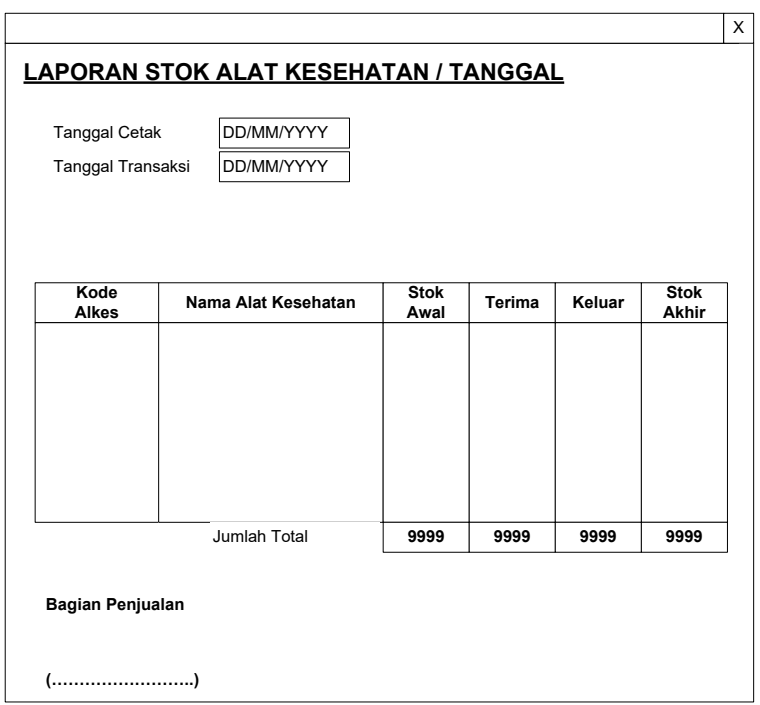

Gambar 26. Laporan Stok Alkes per Tanggal

\section{3) Rancangan Pengujian}

Rancangan pengujian yang dilakukan menggunakan metode Black Box. Pengujian black box berfokus pada persyaratan fungsional perangkat lunak. Pengujian ini memungkinkan analisis sistem memperoleh kumpulan kondisi input yang akan mengerjakan seluruh keperluan fungsional 
program. Tujuan metode ini mencari kesalahan pada:

1. Fungsi yang salah atau hilang

2. Kesalahan pada interface

3. Kesalahan pada struktur data atau akses database

4. Kesalahan performansi

5. Kesalahan inisialisasi dan tujuan akhir.

\section{HASIL DAN PEMBAHASAN}

\section{A. Pembahasan dan Implementasi}

Implementasi sistem administrasi permintaan dan pengiriman alat kesehatan pada PT. Samudra Farma Bengkulu ini dibuat dengan menggunakan bahasa pemrograman Visual Basic 6.0. Fasilitas yang terdapat pada aplikasi ini terdapat beberapa menu yaitu menu file, menu transaksi, menu laporan dan menu keluar. Pada menu file terdapat sub menu alat kesehatan, sub menu pemakai, sub menu supplier dan sub menu pelanggan. Sedangkan pada menu transaksi terdapat sub menu cek stok alkes, sub menu penerimaan alkes dari supplier, sub menu permintaan konsumen dan sub menu pengiriman alat kesehatan. Pada menu laporan terdapat sub menu laporan data master, laporan transaksi, rincian transaksi dan laporan cek stok alat kesehatan per tanggal.

\section{1) Form Login}

Untuk dapat menggunakan atau mengoperasikan aplikasi ini, sistem akan meminta user untuk melakukan login. Halaman login akan tampil seperti gambar berikut ini :

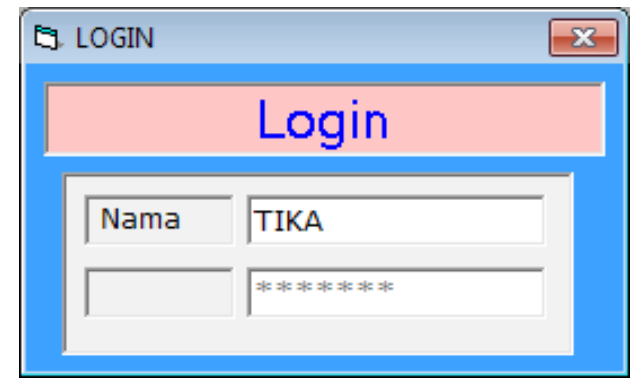

Gambar 27. Login
Apabila pada form login user memasukkan name dan password yang benar maka aplikasi akan dapat digunakan

\section{2) Menu File}

Pada menu file terdapat beberapa sub menu antara lain sub menu alat kesehatan, sub menu pemakai, sub menu supplier dan sub menu pelanggan, seperti tampak pada gambar berikut ini :

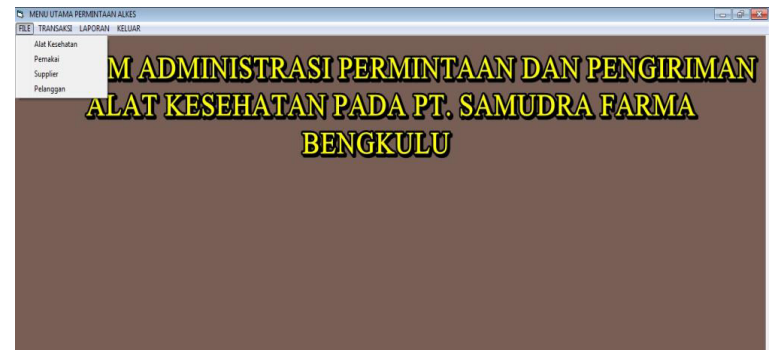

Gambar 28. Menu File

\section{a) Sub Menu File Alat Kesehatan}

Sub menu file alat kesehatan merupakan form input data alat kesehatan yang terdapat di PT. Samudra Farma Bengkulu. Untuk lebih jelas data apa saja yang harus diinputkan pada form data alat kesehatan ini dapat dilihat pada gambar berikut :

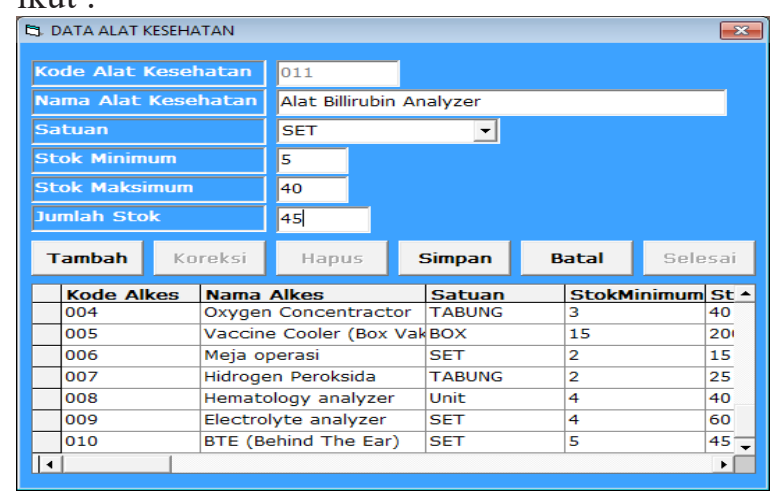

Gambar 29. Input Data Alat Kesehatan

Berdasarkan gambar di atas, dapat dijelaskan bahwa Input data alat kesehatan berfungsi sebagai tatap muka (interface) guna melakukan penambahan data, perbaikan data, pembatalan data, dan penghapusan data alat kesehatan.

\section{b) Sub Menu File Pemakai}

Sub menu file pemakai merupakan form input 
data user atau pemakai yang akan menggunakan aplikasi ini. Untuk lebih jelas data apa saja yang harus diinputkan pada form data alat kesehatan ini dapat dilihat pada gambar berikut.

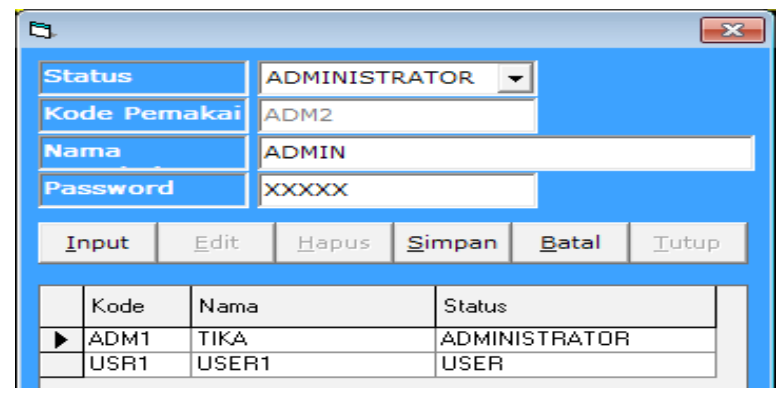

Gambar 30. Input Data Pemakai

\section{c) Sub Menu File Supplier}

Sub menu file supplier merupakan form input data supplier yang terdapat di PT. Samudra Farma Bengkulu. Untuk lebih jelas data apa saja yang harus diinputkan pada form data alat kesehatan ini dapat dilihat pada gambar berikut :

\begin{tabular}{|c|c|c|c|c|c|c|c|}
\hline DATA SUPPLEF & & & & & & & $\underline{\underline{x}}$ \\
\hline Kode Supplit & & 504 & & & / Orang & M. FADLI & \\
\hline Nama Suppli & & PT. JARUM SAKT & & Ema & & FAKBAR@ & Ail.com \\
\hline Telpon / HP & & 02234598299 & & Alan & & JL. A.YAI & 1020 \\
\hline Tambah & Koreksi & Hapus & Simpan & Batal & Selesai & & + \\
\hline $\begin{array}{l}\text { Kode Sup } \\
501\end{array}$ & & \begin{tabular}{|l} 
Nama Suppli \\
PT ALAKAZAM
\end{tabular} & & it & & $\frac{\text { elp / HP }}{233455}$ & \begin{tabular}{|l} 
Person / Orang \\
RYAN HAFIZ
\end{tabular} \\
\hline 502 & & PT SINAR DUN & & AR RAYA & 02182 & 2736432 & TURISNAWATI \\
\hline 503 & & CV PURNA KAR & & DEN PATA & ENGK 07363 & & OPIE PUTRA \\
\hline
\end{tabular}

Gambar 31. Input Data Supplier

\section{d) Sub Menu File Pelanggan}

Sub menu file pelanggan merupakan form input data pelanggan yang terdapat di PT. Samudra Farma Bengkulu. Untuk lebih jelas data apa saja yang harus diinputkan pada form data alat kesehatan ini dapat dilihat pada gambar berikut.

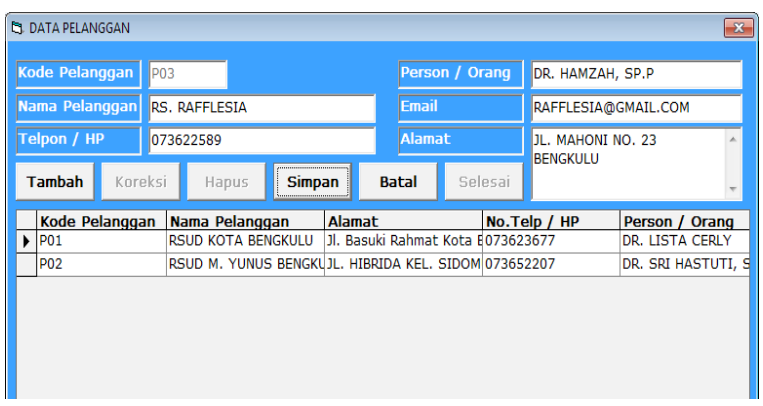

Gambar 31. Input Data Pelanggan

\section{3) Menu Transaksi}

\section{a) Sub Menu Cek Stok digudang}

Sub menu cek stok digudang merupakan sub menu yang berfungsi untuk melihat atau mengetahui ada berapa stok alat kesehatan ada dibawah batas minimum, hal ini diperlukan untuk mengontrol alat kesehatan sehinga pihak perusahaan dapat dengan mudah mengetahui berapa lagi alat yang ada pada gudang. Untuk lebih jelas dapat dilihat pada gambar berikut ini.

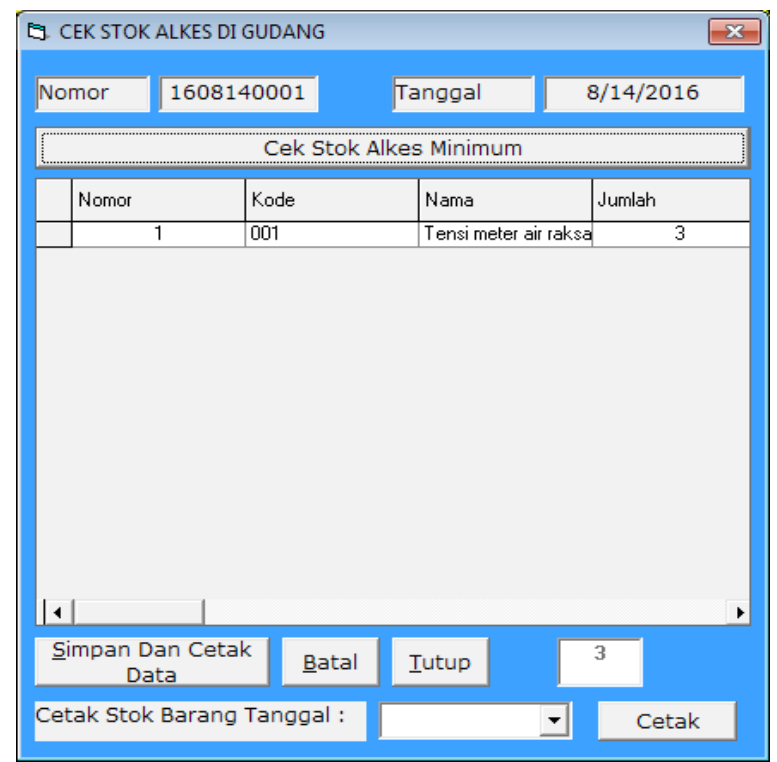

Gambar 33. Cek Stok Alkes di Gudang

Berdasarkan gambar diatas dapat dilihat ada beberapa tombol antara lain simpan dan cetak data, tombol batal, tombol tutup dan tombol cetak. Tombol cetak berfungsi untuk mencetak stok alat kesehatan berdasarkan tanggal yang diinginkan. Sedangkan tombol simpan dan cetak berfungsi untuk menyimpan data dan mencetak stok alat kesehatan yang ada digudang.

\section{b) Penerimaan Alkes dari Supplier}

Pada form transaksi penerimaan alkes dari supplier terdapat nomor penerimaan, tanggal, kode supplier, nama supplier, untuk entri datanya langsung pada grid atau kolom yang telah disediakan, seperti tampak pada gambar berikut. 


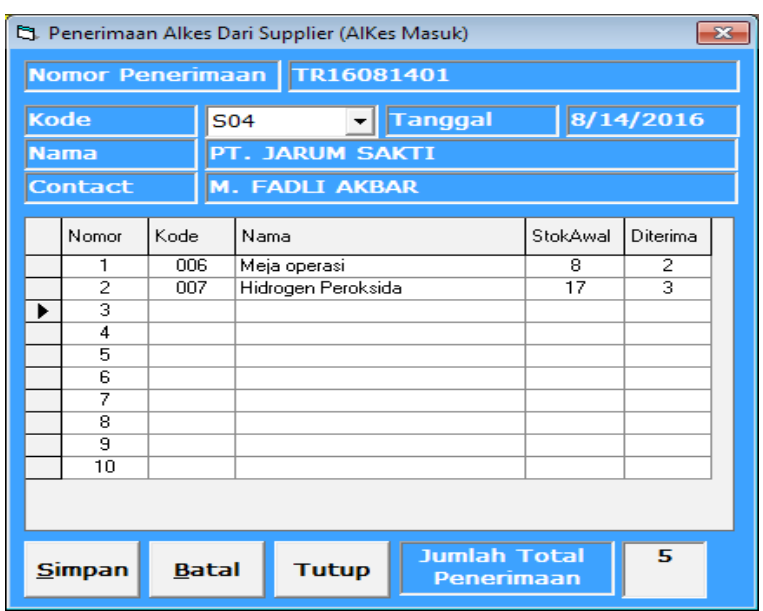

Gambar 34. Form Input Penerimaan Alkes

\section{c) Permintaan Pelanggan}

Form transaksi permintaan bibit merupakan form transaksi yang dilakukan dan berdasarkan dari permintaan para pelanggan kepada pihak PT. Samudra Farma Bengkulu, Proses entri data dilakukan pada grid atau tabel, seperti gambar berikut.

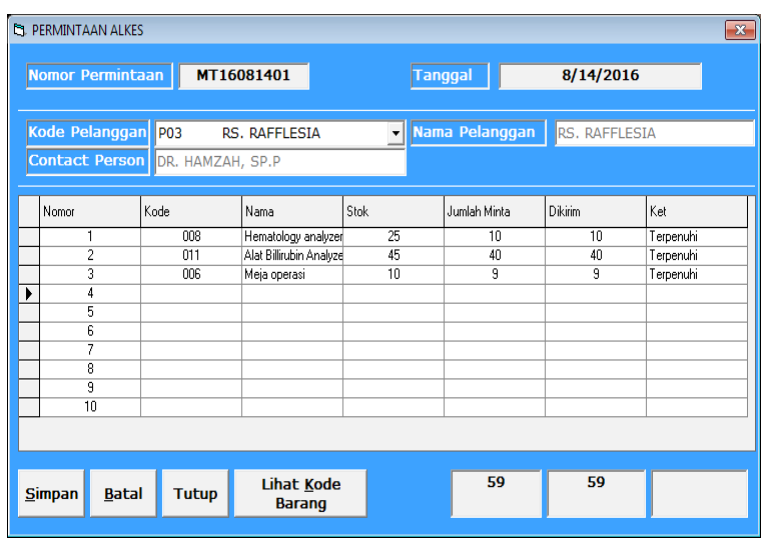

Gambar 35. Input Data Permintaan Alkes

\section{d) Pengiriman Alkes}

Form sub menu transaksi pengiriman alkes merupakan form untuk melakukan pengiriman dan mengetahui jumlah alkes yang diminta oleh para pelanggan dapat terpenuhi atau tidak, untuk lebih jelas dapat dilihat pada gambar berikut.

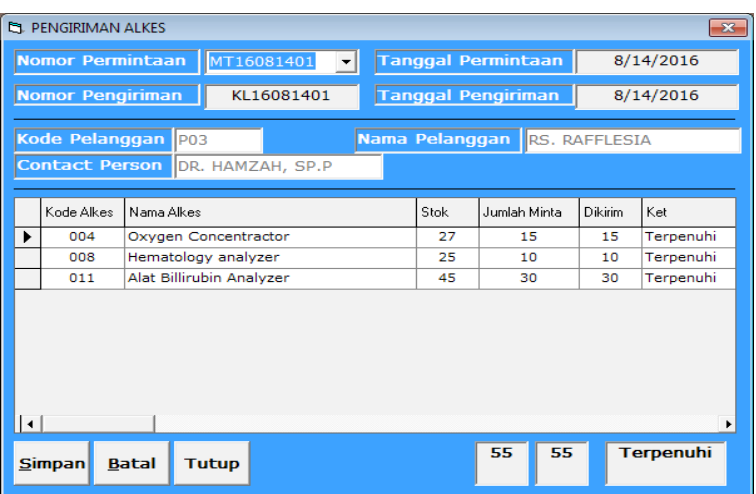

Gambar 36. Form Input Pengiriman Alkes

\section{4) Menu Laporan \\ a) Laporan Data Master}

Laporan data master merupakan laporan yang menampilkan data alat kesehatan, data supplier, data pemakai aplikasi dan data pelanggan. Untuk memilih data laporan dapat dilihat pada gambar berikut ini.

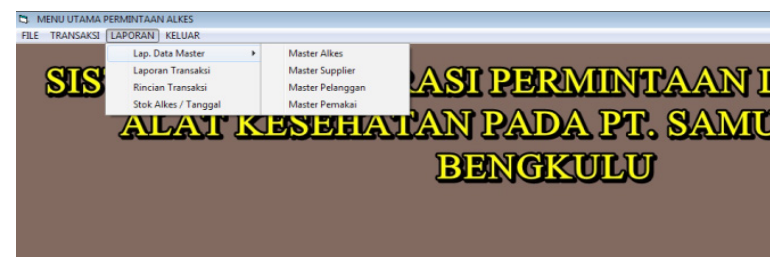

Gambar 37. Menu Laporan

\section{Master Alat Kesehatan}

Laporan master data alat kesehatan merupakan laporan yang berisi tentang nama alat kesehatan dan jumlah alat kesehatan, seperti gambar berikut ini.

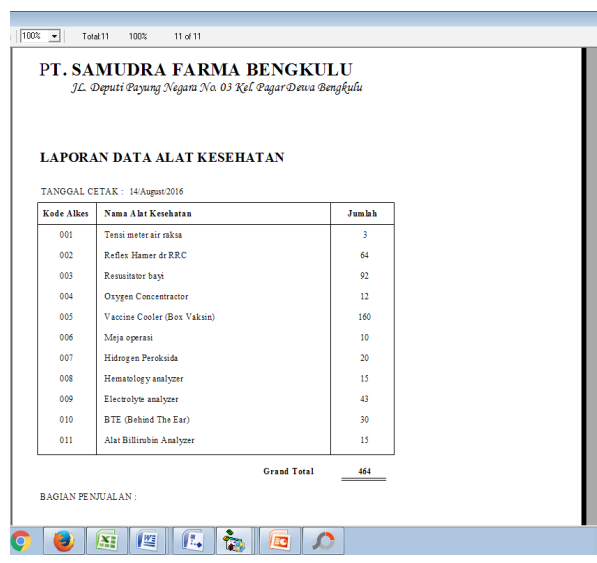

Gambar 38. Laporan Data Alat Kesehatan 


\section{Master Supplier}

\begin{tabular}{|c|c|c|c|c|c|}
\hline \multirow{2}{*}{\multicolumn{6}{|c|}{ 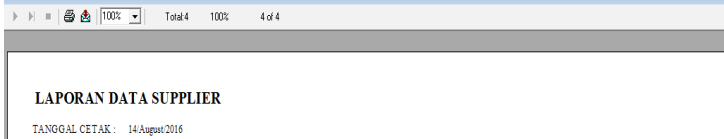 }} \\
\hline & & & & & \\
\hline 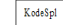 & Nama Suppiater & Alawat & Tretepan AP & 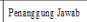 & \begin{tabular}{|l|l|l} 
Emill \\
\end{tabular} \\
\hline 501 & PT ALAKKAZAMM & $\pi$ AMBARANA & 02122334455 & Ryan haflz & 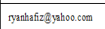 \\
\hline 502 & PT SINAR DENIA & $\pi$ SNARRAYA & 02122736432 & Turbsamami & 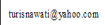 \\
\hline s03 & Cy pURva KarYA & Л.RADEN PATAH BENVKUUU & 01363346454 & OPIE PUTRA & OPIE PTR QONAL.CO \\
\hline 304 & PT. SARTMSAKKII & ת.AYAMNYO 20 & 02235989899 & M.FADLI AKBBAR & FAKBARGGMAT.CO \\
\hline
\end{tabular}

Gambar 39. Laporan Data Supplier

\section{Master Pelanggan}

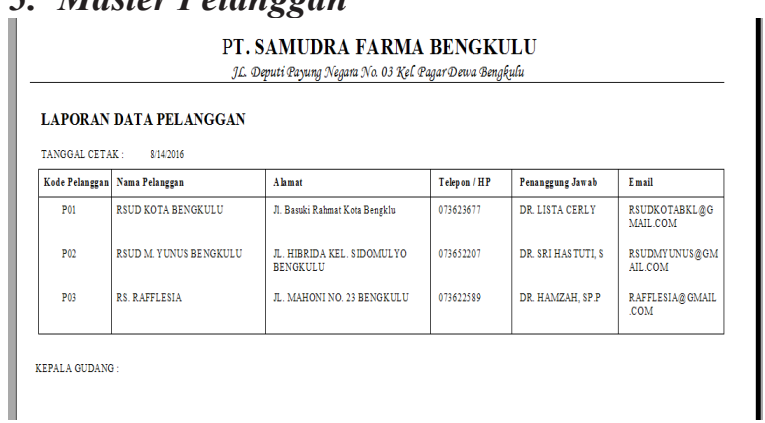

Gambar 40. Laporan Data Pelanggan

\section{Master Pemakai}

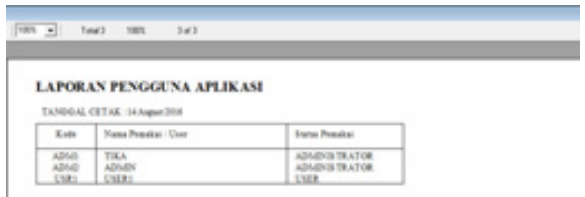

Gambar 41. Laporan Data Pemakai Aplikasi

\section{b) Laporan Transaksi}

Pada laporan transaksi terdapat form untuk memilih laporan transaksi apa yang ingin dicetak, pada form ini terdapat 3 (tiga) pilihan laporan yaitu laporan permintaan, penerimaan dan pengiriman, untuk lebih jelas dapat dilihat pada gambar berikut ini.

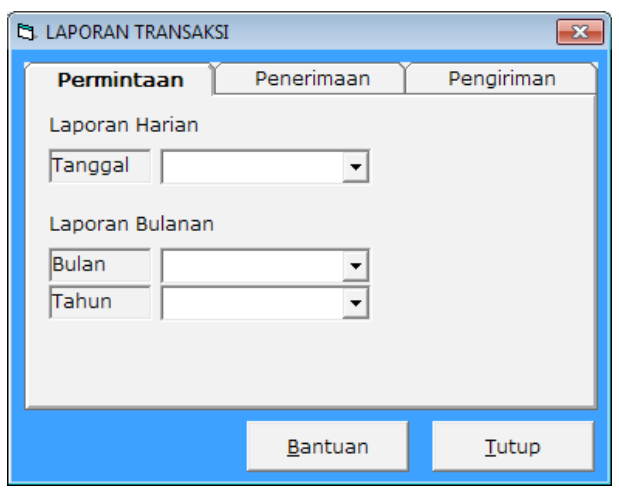

Gambar 42. Form Pilihan Laporan

\section{Laporan Transaksi Harian Permintaan}

Untuk menampilkan laporan harian permintaan, pemakai harus memilih tanggal yang terdapat pada combo, seperti gambar berikut ini.

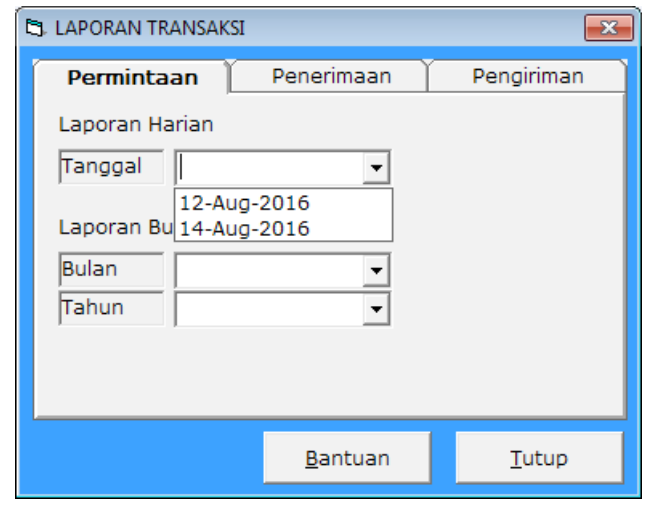

Gambar 43. Pilihan Permintaan Laporan Harian

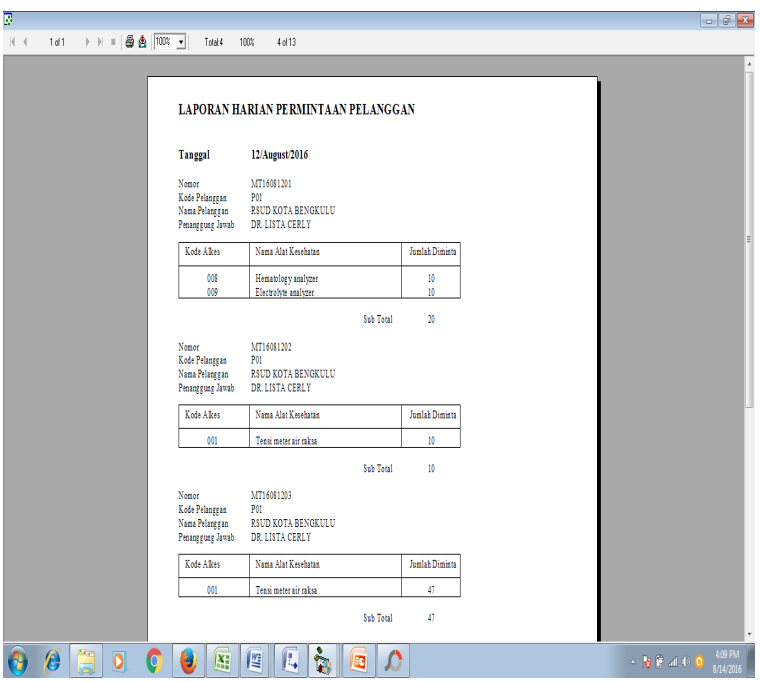

Gambar 44. Laporan Harian Permintaan Pelanggan

\section{Laporan Transaksi Bulanan Permintaan}

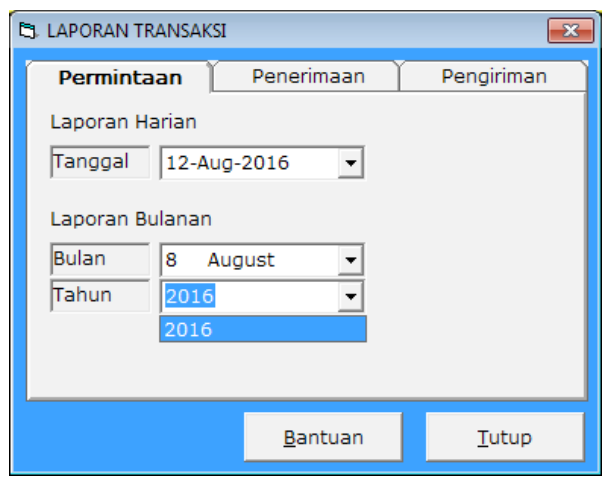

Gambar 45. Pilihan Permintaan Laporan Bulanan 


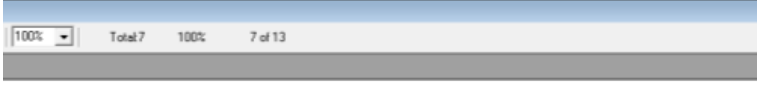

LAPORAN BULANAN PERMINTAAN DARI PELANGGAN

BLLAN AGUSTUS

\begin{tabular}{|c|c|c|}
\hline Kode Aleses & Nama Alkes & Jumiat Minta \\
\hline 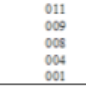 & 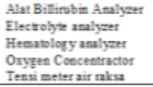 & $\begin{array}{l}30 \\
10 \\
20 \\
15 \\
57\end{array}$ \\
\hline
\end{tabular}

Gambar 46. Laporan Permintaan Bulanan Pelanggan

\section{Laporan Transaksi Harian Penerimaan}

Untuk menampilkan laporan harian penerimaan, pemakai harus memilih tanggal yang terdapat pada combo, seperti gambar berikut ini.

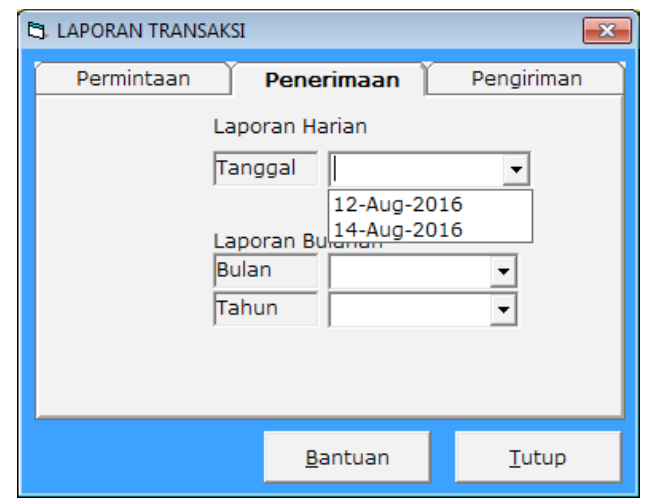

Gambar 47. Pilihan Laporan Penerimaan Harian

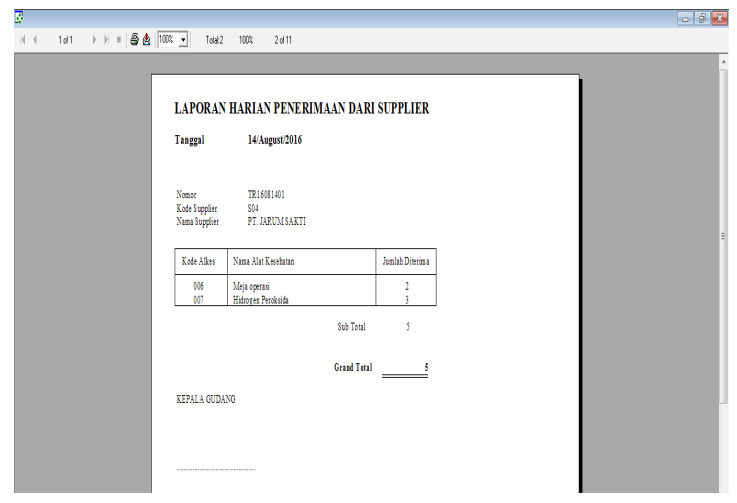

Gambar 48. Laporan Penerimaa Alkes

\section{Laporan Transaksi Bulanan Penerimaan}

Untuk menampilkan laporan bulanan penerimaan, pemakai harus memilih bulan dan tahun yang terdapat pada combo, seperti gambar berikut ini.

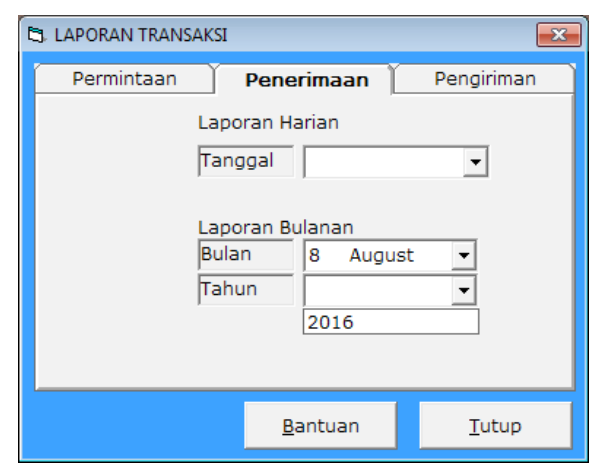

Gambar 49. Pilihan Laporan Penerimaan Bulanan

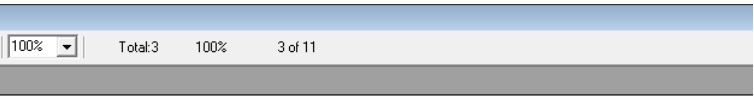

LAPORAN BULANAN PENERIMAAN ALAT KESEHATA
$\begin{aligned} & \text { Bulan } \\
& \text { Tahun }\end{aligned} \begin{aligned} & \text { AGUSTUS } \\
& \mathbf{2 0 1 6}\end{aligned}$
\begin{tabular}{|l|l|c|}
\hline Kode Alkes & Nama Alat Kesehatan & Diterima \\
\hline 007 & $\begin{array}{l}\text { Hidrogen Peroksida } \\
006\end{array}$ & $\begin{array}{l}\text { Meja operasi } \\
\text { Resusitator bayi }\end{array}$ \\
003 & 2 \\
\hline
\end{tabular}
Grand Total

Gambar 50. Laporan Penerimaan Bulanan

\section{Laporan Transaksi Pengiriman Harian}

Untuk menampilkan laporan harian pengiriman, pemakai harus memilih tanggal yang terdapat pada combo, seperti gambar berikut ini.

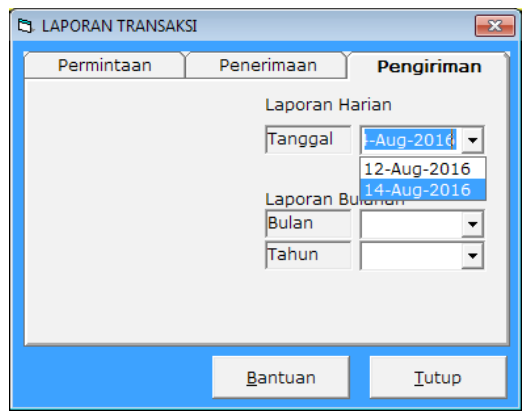

Gambar 51. Pilihan Laporan Pengiriman Harian

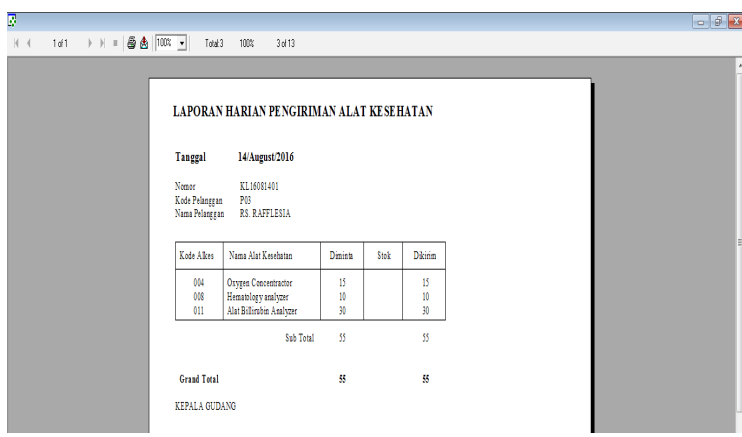

Gambar 52. Laporan Pengiriman Harian Alkes 


\section{Laporan Transaksi Bulanan Penerimaan}

Untuk menampilkan laporan harian pengiriman, pemakai harus memilih bulan dan tahun yang terdapat pada combo, seperti gambar berikut ini.

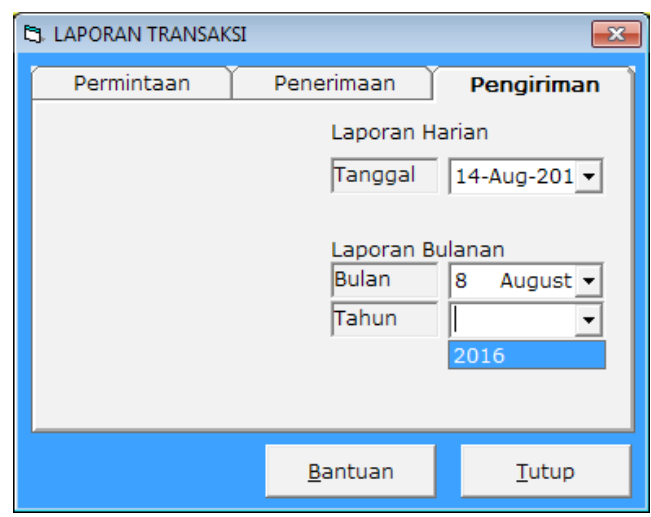

Gambar 53. Pilihan Laporan Pengiriman Bulanan

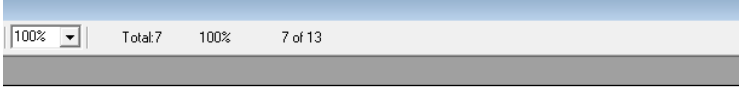

\begin{tabular}{|c|c|c|c|}
\hline $\begin{array}{l}\text { BULAN } \\
\text { TAHUN }\end{array}$ & $\begin{array}{l}\text { AGUSTUS } \\
2016\end{array}$ & & \\
\hline Kode Alkes & Nama Alat Kesehatan & Diminta & Dikirim \\
\hline $\begin{array}{l}011 \\
009 \\
008 \\
004 \\
001\end{array}$ & $\begin{array}{l}\text { Alat Billirubin Analyzer } \\
\text { Electrolyte analyzer } \\
\text { Hematology analyzer } \\
\text { Oxygen Concentractor } \\
\text { Tensi meter air raksa }\end{array}$ & $\begin{array}{l}30 \\
10 \\
20 \\
15 \\
57\end{array}$ & $\begin{array}{l}30 \\
10 \\
20 \\
15 \\
57\end{array}$ \\
\hline
\end{tabular}

Gambar 54. Laporan Pengiriman Alkes Bulanan

\section{c) Rincian Transaksi}

Form rincian transaksi merupakan form untuk melakukan pengecekan atau mengetahui apakah alat kesehatan yang diminta dan yang dikirim terpenuhi atau tidak, untuk lebih jelas dapat dilihat pada gambar berikut :

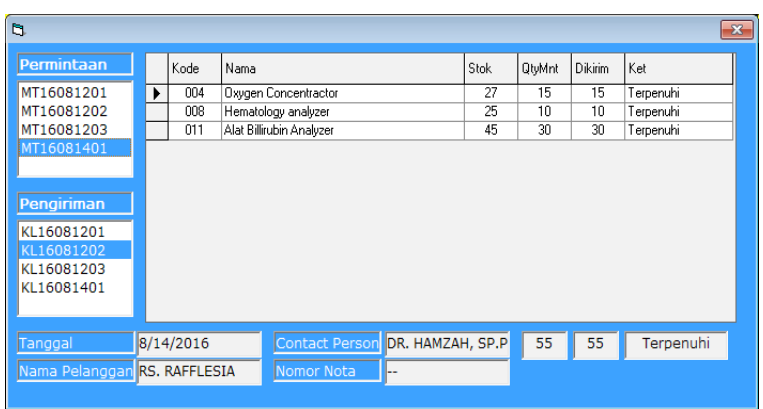

Gambar 55. Rincian Transaksi Permintaan dan Pengiriman

\section{Laporan Stok Alkes / Tanggal}

Laporan stok alkes per tanggal adalah fasilitas yang menampilkan alkes yang diterima, alkes yang keluar dan alkes yang diterima dan keluar berdasarkan tanggal yang akan dipilih oleh user, seperti gambar berikut ini.

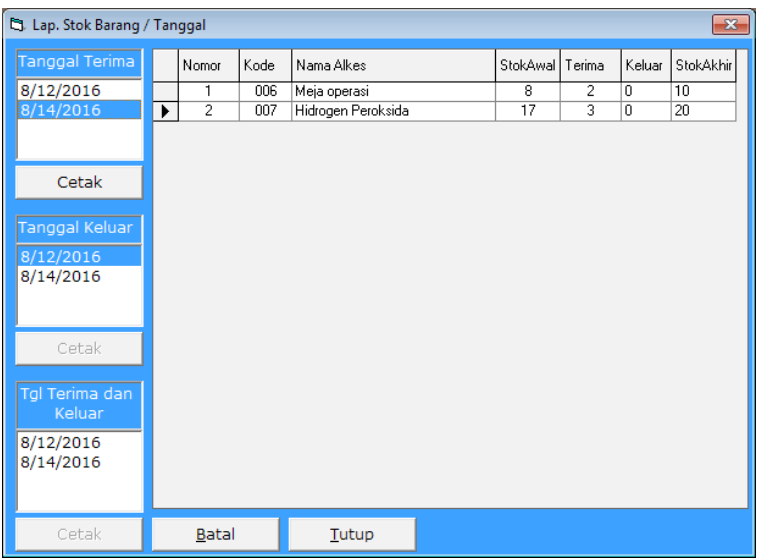

Gambar 56. Pilihan Cetak Laporan Stok diterima / Tanggal

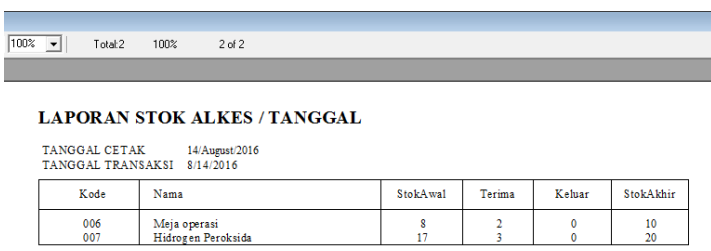

Gambar 57. Laporan Alkes Diterima per Tanggal

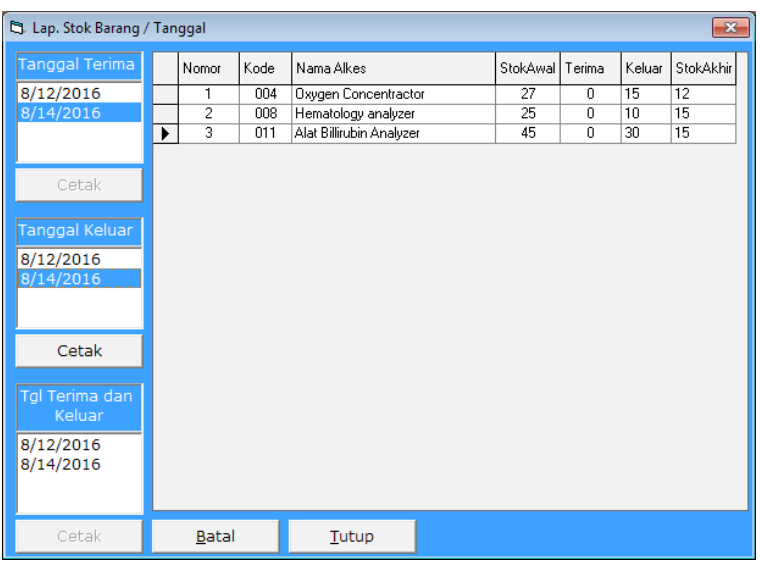

Gambar 58. Pilihan Cetak Laporan Stok Keluar / Tanggal 


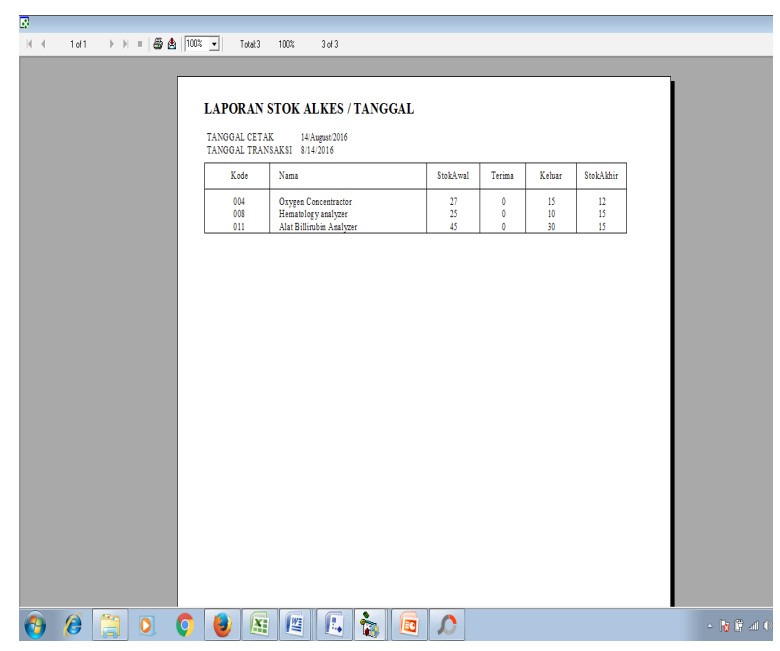

Gambar 59. Laporan Alkes Keluar per Tanggal

\section{B. Pengujian Sistem}

Pengujian sistem dimaksudkan untuk menguji semua elemen-elemen perangkat lunak yang telah dibuat apakah sudah sesuai dengan yang diharapkan. Pada pengujian Aplikasi Samudra_Farma. Exe ada beberapa hal yang akan diuji terlihat pada tabel 7.

Tabel 7. Pengujian Aplikasi

\begin{tabular}{|l|l|l|}
\hline Kelas Uji & \multicolumn{1}{|c|}{ Keterangan } & Jenis Pengujian \\
\hline Login & Login & Black Box \\
\hline Input Data & $\begin{array}{l}\text { Input Data alkes, data pema- } \\
\text { kai, data supplier, data pelang- } \\
\text { gan, }\end{array}$ & Black Box \\
\hline Transaksi & $\begin{array}{l}\text { Cek stok alkes, permintaan, } \\
\text { penerimaan dan pengiriman } \\
\text { alkes }\end{array}$ & Black Box \\
\hline Laporan & Laporan Hasil Pengujian & Black Box \\
\hline
\end{tabular}

Berikut hasil pengujian sistem metode black box berdasarkan tabel diatas.

\section{1) Pengujian Login}

Tabel 8. Hasil Pengujian Login

\begin{tabular}{|l|l|l|l|}
\hline $\begin{array}{l}\text { Data yang di- } \\
\text { masukan }\end{array}$ & $\begin{array}{l}\text { Yang diha- } \\
\text { rapkan }\end{array}$ & Pengamatan & Kesimpulan \\
\hline Username dan & Bisa meng- & Aplikasi bisa & Diterima \\
Password terisi & kases menu \\
dengan benar & dijalankan & \\
menjalankan & aplikasi & & \\
\hline Username & $\begin{array}{l}\text { Akan me- } \\
\text { nampilkan } \\
\text { dan Password }\end{array}$ & $\begin{array}{l}\text { Akan menam- } \\
\text { pilkan pesan- }\end{array}$ & Diterima \\
kosong atau & "kesempatan & "kesempatan & \\
Username dan & salah" & ke 1 salah" & \\
Password salah & & & \\
\hline
\end{tabular}

\section{2) Pengujian Input Data}

Tabel 9. Hasil Pengujian Input Data

\begin{tabular}{|c|c|c|c|}
\hline \multicolumn{4}{|c|}{ Kasus dan Hasil Uji (Data Normal) } \\
\hline Data Masukan & $\begin{array}{l}\text { Yang diha- } \\
\text { rapkan }\end{array}$ & Pengamatan & Kesimpulan \\
\hline Klik "Tambah" & $\begin{array}{l}\text { Tombol yang } \\
\text { aktif hanya } \\
\text { tombol } \\
\text { "Simpan" } \\
\text { dan tombol } \\
\text { "Batal" }\end{array}$ & $\begin{array}{l}\text { Dapat } \\
\text { mengisi tiap } \\
\text { field sesuai } \\
\text { dengan yang } \\
\text { diharapkan }\end{array}$ & Diterima \\
\hline Klik "Simpan" & $\begin{array}{l}\text { Data tersim- } \\
\text { pan }\end{array}$ & $\begin{array}{l}\text { Tombol } \\
\text { "Simpan" } \\
\text { berfungsi } \\
\text { sesuai yang } \\
\text { diharapkan }\end{array}$ & Diterima \\
\hline Klik "Koreksi" & $\begin{array}{l}\text { Data diper- } \\
\text { baharui }\end{array}$ & $\begin{array}{l}\text { Tombol } \\
\text { "Koreksi" } \\
\text { berfungsi } \\
\text { sesuai yang } \\
\text { diharapkan }\end{array}$ & Diterima \\
\hline Klik "Hapus" & $\begin{array}{l}\text { Data terha- } \\
\text { pus }\end{array}$ & $\begin{array}{l}\text { Tombol } \\
\text { "Hapus" } \\
\text { berfungsi } \\
\text { sesuai yang } \\
\text { diharapkan }\end{array}$ & Diterima \\
\hline Klik "Batal" & $\begin{array}{l}\text { Data tidak } \\
\text { jadi di isi }\end{array}$ & $\begin{array}{l}\text { Tombol } \\
\text { "Batal" } \\
\text { berfungsi } \\
\text { sesuai yang } \\
\text { diharapkan }\end{array}$ & \\
\hline
\end{tabular}

\begin{tabular}{|l|l|l|l|}
\hline \multicolumn{4}{|l|}{ Kasus dan Hasil Uji (Data Salah) } \\
\hline Data Masukan & $\begin{array}{l}\text { Yang diharap- } \\
\text { kan }\end{array}$ & $\begin{array}{l}\text { Penga- } \\
\text { matan }\end{array}$ & Kesimpulan \\
\hline Pengisian & Muncul pesan & $\begin{array}{l}\text { Textbox } \\
\text { berfungsi }\end{array}$ & Diterima \\
textbox kode & bahwa data & & \\
kurang dari 3 & harus di isi de- & $\begin{array}{l}\text { sesuai de- } \\
\text { ngan yang } \\
\text { digharap- } \\
\text { ngan 3 digit }\end{array}$ & \\
& & kan & \\
\hline
\end{tabular}

\section{PENUTUP}

\section{A. Kesimpulan}

Berdasarkan hasil pengamatan yang telah dilakukan melalui implementasi dan penerapan pemakaian program pada PT. Samudra Farma Bengkulu, dapat disimpulkan sebagai berikut :

1. Aplikasi Sistem Administrasi Permintaan dan Pengiriman Alat Kesehatan ini dibuat dengan menggunakan bahasa pemrogra- 
man Visual Basic 6.0.

2. Aplikasi Sistem Administrasi Permintaan dan Pengiriman Alat Kesehatan yang telah dibuat menyediakan fasilitas untuk mengolah data meliputi menambah, mengkoreksi, menyimpan dan menghapus data Permintaan dan pengiriman alat kesehatan.

3. Aplikasi Sistem Administrasi Permintaan dan Pengiriman Alat Kesehatan ini dapat membantu pihak PT. Samudra Farma Bengkulu dalam mengetahui kebutuhan dan keuangan PT. Samudra Farma Bengkulu.

\section{B. Saran}

Berdasarkan pembahasan dan kesimpulan yang telah diuraikan di atas, saran dan rekomendasi yang dapat diberikan adalah :

1. Agar Aplikasi Sistem Administrasi Permintaan dan Pengiriman Alat Kesehatan lebih dikenal secara luas, maka perlu kiranya adanya program yang mampu diakses secara On-line.

2. Untuk kemudian hari diharapkan dapat dilakukan pengembangan aplikasi yang dapat dilakukan menggunakan aplikasi lain seperti java yang dapat diakses melalui heandphone ataupun aplikasi lainnya.

\section{DAFTAR PUSTAKA}

Dhanta, R. (2009). Pengantar Ilmu Komputer. Surabaya: Indah.

Fachreza, Negara, S., \& Salmia. (2012). Analisis Faktor-Faktor Yang Mempengaruhi Permintaan Gula Pasir Di Kota Medan. Agrobisnis , 1-14.

Fatta, A. (2009). Analisi dan Perancangan Sistem Informasi Untuk Keunggulan Bersaing Perusahaan dan Organisasi Modern. Yogyakarta: Andi Offset.

Fathansyah. (2012). Basis Data. Bandung : Infor- matika

Mufiz, H.M (2004). Ilmu Komunikasi dan Administrasi Publik, Sebuat Tinjauan Filosofi. Bandung: Kanisius.

Retrieved Maret 18, 2016, from www.Wikipedia. org: www.Wikipedia.org

Rowianto, Viarna, A. P., Dewi, \& Honggo, H. (2008). Aplikasi Pengelolaan Data Pencatatan Transaksi Pengiriman Barang Pada PT. Jantera Multi Sarana. Teknologi Informasi , 1-11.

Sholeh, M. (2008). Permintaan dan Penawaran Tenaga Kerja Serta Upah. Ekonomi , 1-13.

Yakub. (2012). Pengantar Sistem Informasi. Yogyakarta: Graha Ilmu.

Yuswanto. (2008). Pengenalan Visual Basic 6.0. Jakarta: Bumi Aksara. 